Supporting Information for

\title{
Substituent Effect in the Reactions between Criegee Intermediates and 3-Aminopropanol
}

Mei-Tsan Kuo, ${ }^{1}$ Jie-Ning Yang, ${ }^{1,2}$ Jim Jr-Min Lin, ${ }^{1,2^{*}}$ Kaito Takahashi ${ }^{1 *}$

1. Institute of Atomic and Molecular Sciences, Academia Sinica, Taipei 10617, Taiwan

2. Department of Chemistry, National Taiwan University, Taipei 10617, Taiwan

Summary of the experimental conditions and results;

Discussion on the errors of the quantum-chemistry methods and errors due to harmonic approximation; assumptions for the use of transition state theory, barrier energies for reaction with water vapor, and optimized XYZ geometries.

Appendix: Measurement of the absolute absorption cross sections of 1,3-diiodo-but-2-ene. 


\section{EXPERIMENTAL DETAILS}

Table S1. Summary of the experimental conditions and results for the reaction of $\left(\mathrm{CH}_{3}\right)_{2} \mathrm{COO}+$ $\mathrm{NH}_{2} \mathrm{C}_{3} \mathrm{H}_{6} \mathrm{OH} .\left[\mathrm{O}_{2}\right]=3.15 \times 10^{17} \mathrm{~cm}^{-3} ; k$ represents the bimolecular reaction rate coefficient.

\begin{tabular}{ccccccc}
\hline Exp\# & $\begin{array}{c}{\left[\left(\mathrm{CH}_{3}\right)_{2} \mathrm{I}_{2}\right]} \\
/ 10^{13} \mathrm{~cm}^{-3}\end{array}$ & $\begin{array}{c}I_{248 \mathrm{~nm}} \\
/ \mathrm{mJ} \mathrm{cm}^{-2}\end{array}$ & $\begin{array}{c}T \\
/ \mathrm{K}\end{array}$ & $\begin{array}{c}P_{\text {total }} \\
/ \text { Torr }\end{array}$ & $\begin{array}{c}k_{0} \\
/ \mathrm{s}^{-1}\end{array}$ & $\begin{array}{c}k \\
/ 10^{-11} \mathrm{~cm}^{3} \mathrm{~s}^{-1}\end{array}$ \\
\hline A1 & 5.9 & 2.45 & 300.3 & 304.2 & $526 \pm 142^{a}$ & $1.46 \pm 0.03^{a}$ \\
\hline A2 & 10.9 & 2.46 & 300.3 & 305.2 & $806 \pm 73$ & $1.49 \pm 0.08$ \\
\hline A3 & 15.0 & 2.45 & 300.3 & 305.0 & $892 \pm 134$ & $1.56 \pm 0.08$ \\
\hline A4 & 10.5 & 2.49 & 297.8 & 300.6 & $726 \pm 56$ & $1.55 \pm 0.02$ \\
\hline A5 & 11.8 & 2.49 & 298.1 & 199.6 & $643 \pm 127$ & $1.53 \pm 0.03$ \\
\hline A6 & 10.3 & 2.47 & 298.2 & 101.2 & $664 \pm 177$ & $1.52 \pm 0.03$ \\
\hline \multicolumn{5}{c}{ Average: } \\
\hline
\end{tabular}

${ }^{a}$ Averaged value \pm 1 sigma error of the mean of the intercept (or slope) from the linear fitting (statistical only, not including any systematic error yet).

${ }^{b}$ Standard deviation of the six data points. This represents the statistical error $\left(\delta_{\mathrm{fit}}=0.04 / 1.52=\right.$ $2.6 \%)$.

The error of $\left[\mathrm{NH}_{2} \mathrm{C}_{3} \mathrm{H}_{6} \mathrm{OH}\right]$ mainly comes from the reported $\mathrm{UV}$ absorption cross sections of $\mathrm{NH}_{2} \mathrm{C}_{3} \mathrm{H}_{6} \mathrm{OH}$, which is ca. $2.1 \%$ (one standard deviation). ${ }^{1}$ 
Table S2. Summary of the experimental conditions and results for the reaction MVKO + $\mathrm{NH}_{2} \mathrm{C}_{3} \mathrm{H}_{6} \mathrm{OH}$. $\left[\mathrm{O}_{2}\right]=3.30 \times 10^{17} \mathrm{~cm}^{-3} ; T=298 \mathrm{~K}$. [Precursor] is the concentration of the 1,3diiodobut-2-ene precursor deduced from the absorbance measurements and the absorption cross sections (See Appendix).

\begin{tabular}{ccccccccc}
\hline Exp\# & $\begin{array}{c}\text { Precursor }] \\
/ 10^{12} \mathrm{~cm}^{-3}\end{array}$ & $\begin{array}{c}I_{248 \mathrm{~nm}} \\
/ \mathrm{mJ} \mathrm{cm}^{-2}\end{array}$ & $\begin{array}{c}P_{\text {total }} \\
/ \text { Torr }\end{array}$ & $1-\alpha$ & $\begin{array}{c}k_{2} \\
/ 10^{3} \mathrm{~s}^{-1}\end{array}$ & $\begin{array}{c}k_{0} \\
/ \mathrm{s}^{-1}\end{array}$ & $\begin{array}{c}k_{3 \text { raw }} \\
/ 10^{-13} \mathrm{~cm}^{3} \mathrm{~s}^{-1}\end{array}$ & $\begin{array}{c}k_{3} \\
/ 10^{-13} \mathrm{~cm}^{3} \mathrm{~s}^{-1}\end{array}$ \\
\hline B1 & 7.8 & 2.3 & 303.7 & 0.88 & 1.09 & $152 \pm 2^{a}$ & $1.41^{b} \pm 0.02^{a}$ & $1.56^{b} \pm 0.02$ \\
\hline B2 & 8.2 & 1.1 & 304.8 & 0.88 & 1.08 & $111 \pm 3$ & $1.50 \pm 0.03$ & $1.61 \pm 0.03$ \\
\hline B3 & 14.2 & 2.3 & 296.6 & 0.85 & 1.31 & $213 \pm 2$ & $1.18 \pm 0.02$ & $1.31 \pm 0.03$ \\
\hline B4 & 14.0 & 2.3 & 297.1 & 0.86 & 1.27 & $213 \pm 3$ & $1.21 \pm 0.03$ & $1.39 \pm 0.03$ \\
\hline B5 & 13.9 & 2.3 & 305.5 & 0.87 & 1.33 & $202 \pm 1$ & $1.39 \pm 0.01$ & $1.46 \pm 0.03$ \\
\hline B6 & 12.3 & 2.1 & 303.0 & 0.88 & 1.25 & $182 \pm 2$ & $1.24 \pm 0.05$ & $1.46 \pm 0.06$ \\
\hline B7 & 11.7 & 2.1 & 107.9 & 0.80 & 1.18 & $174 \pm 4$ & $1.08 \pm 0.08$ & $1.30 \pm 0.08$ \\
\hline B8 & 13.1 & 2.1 & 298.5 & 0.87 & 1.29 & $191 \pm 2$ & $1.09 \pm 0.02$ & $1.40 \pm 0.04$ \\
\hline B9 & 12.4 & 2.1 & 97.9 & 0.78 & 1.26 & $173 \pm 4$ & $1.09 \pm 0.04$ & $1.44 \pm 0.03$ \\
\hline B10 & 12.8 & 2.1 & 300.3 & 0.88 & 1.30 & $181 \pm 3$ & $1.00 \pm 0.05$ & $1.43 \pm 0.05$ \\
\hline & & & & & Average: & 1.22 & 1.44 \\
& & & & & Standard deviation: & \\
\hline
\end{tabular}

${ }^{a}$ Averaged value \pm 1 sigma error of the mean of the intercept (or slope) from the linear fitting (statistical only, not including any systematic error yet).

${ }^{b} k_{3 \text { raw }}$ represents the bimolecular reaction rate coefficient obtained from the pseudo-first-order plot of $k_{\text {obs }}$ against $\left[\mathrm{NH}_{2} \mathrm{C}_{3} \mathrm{H}_{6} \mathrm{OH}\right]$ (e.g., Figures 5, S5-S6), while $k_{3}$ represents the corrected bimolecular reaction rate coefficient (e.g., from Figures S8-S9).

${ }^{c}$ Standard deviation of the ten data points. This represents the statistical error $\left(\delta_{\text {fit }}=0.16 / 1.22=\right.$ $13 \%$ for $k_{3 \text { raw }}, \delta_{\text {fit }}=0.10 / 1.44=6.9 \%$ for $\left.k_{3}\right)$.

Final error estimation. The correction model for $k_{3}$ is an approximation, of which the uncertainty is not well established yet. However, we believe that its error should be less than the difference between $k_{3 \text { raw }}$ and $k_{3}(0.22 / 1.44=15 \%)$. Other errors like $\delta_{\text {fit }}$ are relatively minor. As a result, we report $k_{3}=(1.44 \pm 0.22) \times 10^{-13} \mathrm{~cm}^{3} \mathrm{~s}^{-1}$. 
Table S3. Experimental conditions for determining the concentrations of the precursors and reactant.

\begin{tabular}{ccccc}
\hline & $\begin{array}{c}\text { Wavelength range } \\
\text { /nm }\end{array}$ & $\begin{array}{c}\text { Light path length } \\
/ \mathrm{cm}\end{array}$ & Light source & Spectrometer \\
\hline$\left(\mathrm{CH}_{3}\right)_{2} \mathrm{CI}_{2}$ & $260-400$ & 75.3 & $\begin{array}{c}\text { Hamamatsu, } \\
\text { L10904 }\end{array}$ & $\begin{array}{c}\text { Ocean Optics, } \\
\text { USB 2000 }\end{array}$ \\
\hline 1,3 -diiodo-but-2-ene & $220-280$ & 75.3 & $\begin{array}{c}\text { Hamamatsu, } \\
\text { L10904 }\end{array}$ & $\begin{array}{c}\text { Ocean Optics, } \\
\text { USB 2000 }\end{array}$ \\
\hline $\mathrm{NH}_{2} \mathrm{C}_{3} \mathrm{H}_{6} \mathrm{OH}$ & $190-240$ & 90.4 & $\begin{array}{c}\text { Hamamatsu, } \\
\text { L12515 }\end{array}$ & $\begin{array}{c}\text { Ibsen photonic, } \\
\text { FHW-380 }\end{array}$ \\
\hline (Downstream cell) & $190-400$ & 66.0 & $\begin{array}{c}\text { Hamamatsu, } \\
\text { L10671D }\end{array}$ & $\begin{array}{c}\text { Ocean Optics, } \\
\text { Flame }\end{array}$ \\
\hline
\end{tabular}

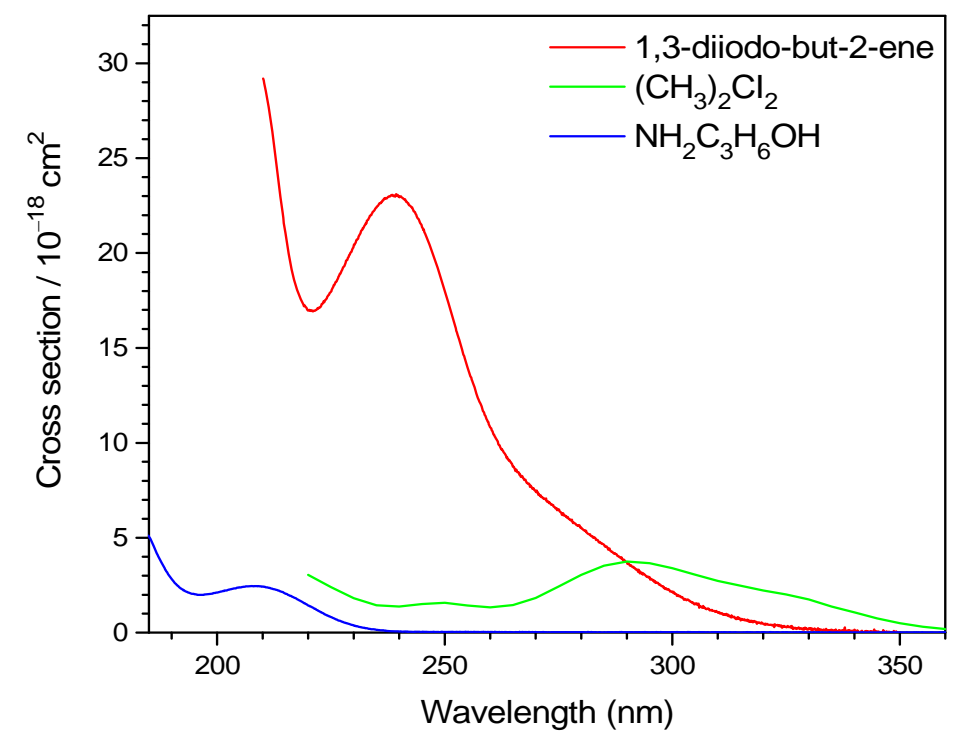

Figure S1. The absolute absorption cross sections of 1,3-diiodo-but-2-ene, $\left(\mathrm{CH}_{3}\right)_{2} \mathrm{CI}_{2}$, and $\mathrm{NH}_{2} \mathrm{C}_{3} \mathrm{H}_{6} \mathrm{OH}$. The cross sections of $\left(\mathrm{CH}_{3}\right)_{2} \mathrm{CI}_{2}$ and $\mathrm{NH}_{2} \mathrm{C}_{3} \mathrm{H}_{6} \mathrm{OH}$ are from the data in the literature. ${ }^{1,2}$ The cross sections of 1,3-diiodo-but-2-ene are determined through measuring the weight loss in experiments of a well-controlled condition of gas flow and concentrations (details are given in the Appendix of SI). 


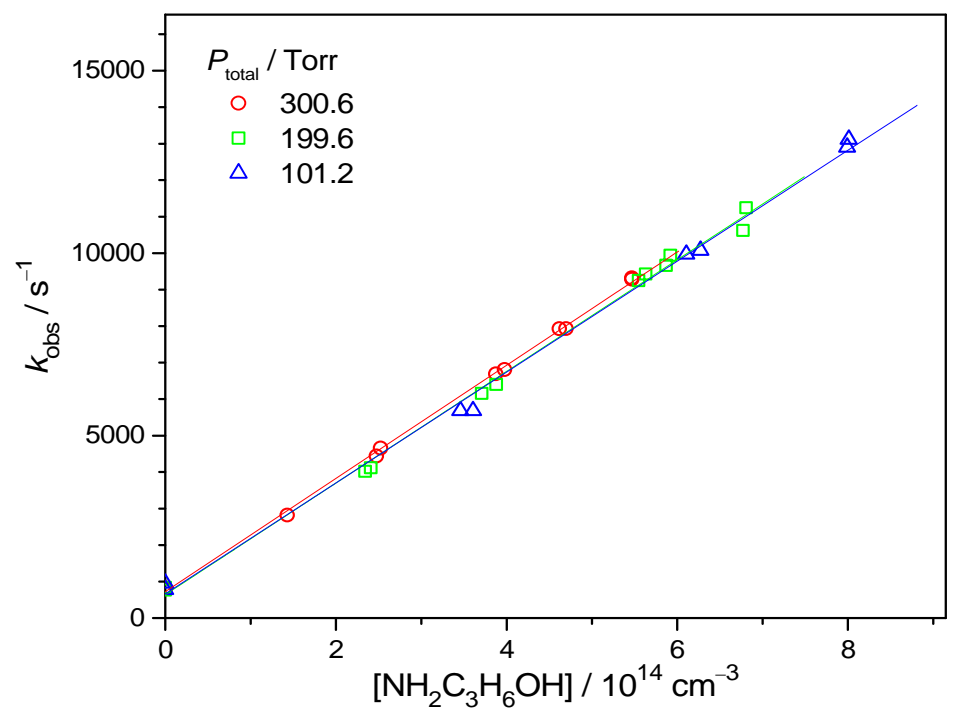

Figure S2. Plot of $k_{\mathrm{obs}}$ of $\left(\mathrm{CH}_{3}\right)_{2} \mathrm{COO}$ against $\left[\mathrm{NH}_{2} \mathrm{C}_{3} \mathrm{H}_{6} \mathrm{OH}\right]$ at various total pressure $P_{\text {total }}$ (Exp A4-A6).

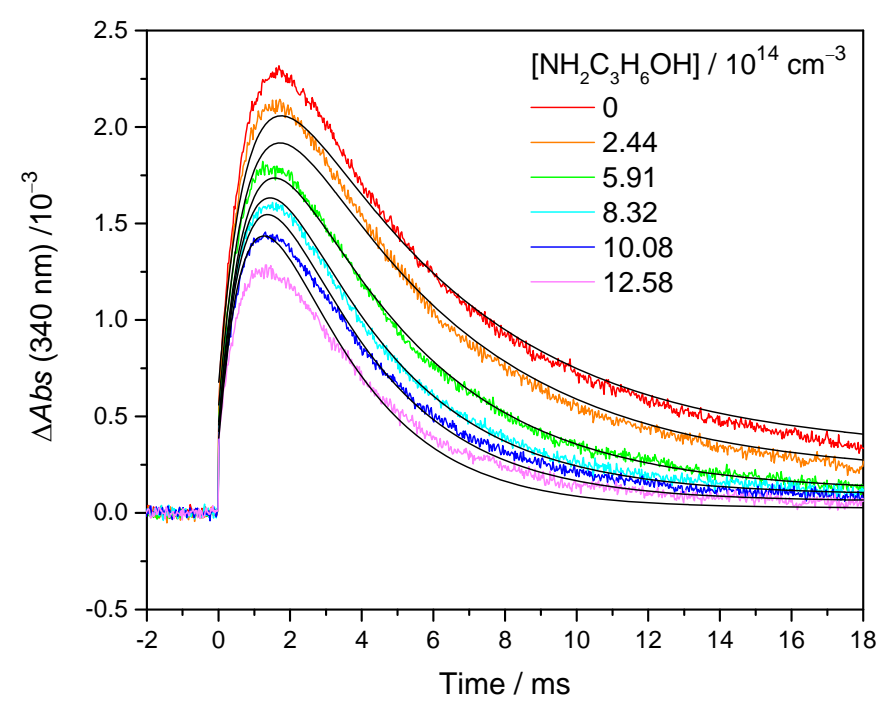

Figure S3. Representative time traces of $\mathrm{MVKO}+\mathrm{NH}_{2} \mathrm{C}_{3} \mathrm{H}_{6} \mathrm{OH}$ reaction (Exp B8) and the fitting traces of (eq. 7) (black lines) while $1-\alpha, \sigma L[\mathrm{MVKO}]_{\text {total }}$, and $k_{2}$ were set as global parameters ( $k_{\mathrm{obs}}$ was set as a local parameter). The fitting traces deviate from the experimental traces, indicating that one of the global parameters is correlated to $\left[\mathrm{NH}_{2} \mathrm{C}_{3} \mathrm{H}_{6} \mathrm{OH}\right]$. 


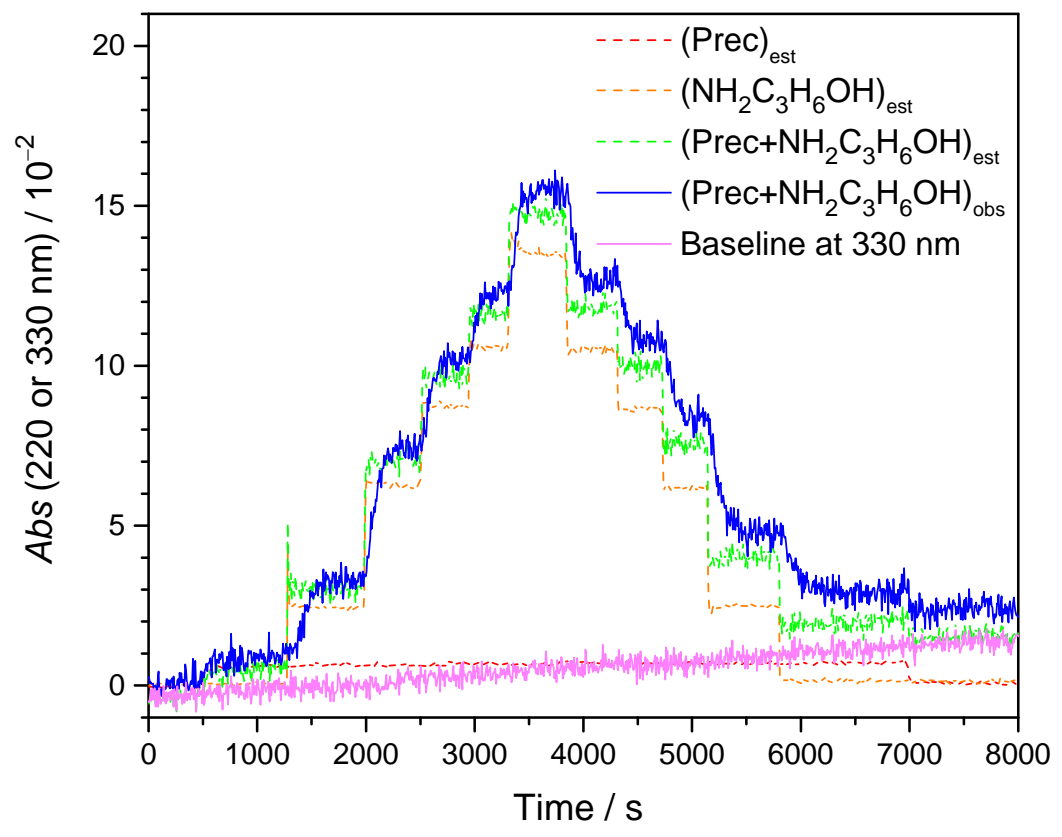

Figure S4. The observed and estimated absorbance $A b s$ of the MVKO precursor (1,3-diiodobut2-ene, Prec) and $\mathrm{NH}_{2} \mathrm{C}_{3} \mathrm{H}_{6} \mathrm{OH}$ at $220 \mathrm{~nm}$ and baseline at $330 \mathrm{~nm}$ at an absorption cell downstream of the reactor (Exp B1). Dashed-lines represent the absorbance estimated from the absorption measurements at the upstream cells after considering the gas dilution, while the solid lines represent the data directly recorded at the downstream cell. A baseline shift of the downstream data (evidenced by the data at $330 \mathrm{~nm}$ where neither the precursor nor $\mathrm{NH}_{2} \mathrm{C}_{3} \mathrm{H}_{6} \mathrm{OH}$ absorbs light) was found in the $\left(\mathrm{Prec}+\mathrm{NH}_{2} \mathrm{C}_{3} \mathrm{H}_{6} \mathrm{OH}\right)_{\text {obs. }}$. This was due to the instability of the used $\mathrm{D}_{2}$ lamp. Therefore, we have included the baseline at $330 \mathrm{~nm}$ in the estimated absorbance $\left(\text { Prec }+\mathrm{NH}_{2} \mathrm{C}_{3} \mathrm{H}_{6} \mathrm{OH}\right)_{\text {est }}$, although the baseline shift at $220 \mathrm{~nm}$ appears to be a bit more severe than that at $330 \mathrm{~nm}$. The experiment was designed to scan $\left[\mathrm{NH}_{2} \mathrm{C}_{3} \mathrm{H}_{6} \mathrm{OH}\right]$ from zero to the maximum and then from the maximum back to zero in a step-like manner, while the precursor concentration [Prec] was fixed. Except some initial overshooting in the "upstairs" part of $\left(\mathrm{NH}_{2} \mathrm{C}_{3} \mathrm{H}_{6} \mathrm{OH}\right)_{\text {est }}$, the upstream absorption signals of $\mathrm{NH}_{2} \mathrm{C}_{3} \mathrm{H}_{6} \mathrm{OH}$ (see $\left(\mathrm{NH}_{2} \mathrm{C}_{3} \mathrm{H}_{6} \mathrm{OH}\right)_{\text {est }}$ ) were quite well controlled; however, the response in the downstream signal was much slower, probably due to much longer gas tubing $\left(\mathrm{NH}_{2} \mathrm{C}_{3} \mathrm{H}_{6} \mathrm{OH}\right.$ would adsorb on and desorb from the tube wall). Thus, the kinetic time traces of $\mathrm{MVKO}$ were acquired during the latter half period of each $\mathrm{NH}_{2} \mathrm{C}_{3} \mathrm{H}_{6} \mathrm{OH}$ concentration step where the downstream concentrations of $\mathrm{NH}_{2} \mathrm{C}_{3} \mathrm{H}_{6} \mathrm{OH}$ were consistent with those estimated from the upstream measurements. 


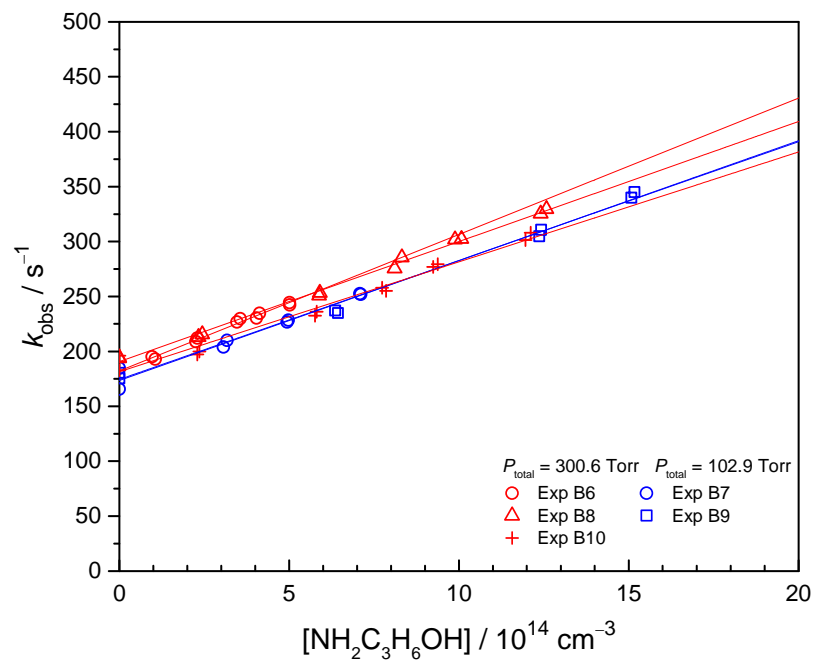

Figure S5. Plot of $k_{\text {obs }}$ of MVKO against $\left[\mathrm{NH}_{2} \mathrm{C}_{3} \mathrm{H}_{6} \mathrm{OH}\right]$ at various experimental conditions (Exp B6-B10). The slope of the linear fitting would be $k_{3 \text { raw }}$ for the $\mathrm{MVKO}+\mathrm{NH}_{2} \mathrm{C}_{3} \mathrm{H}_{6} \mathrm{OH}$ reaction. 


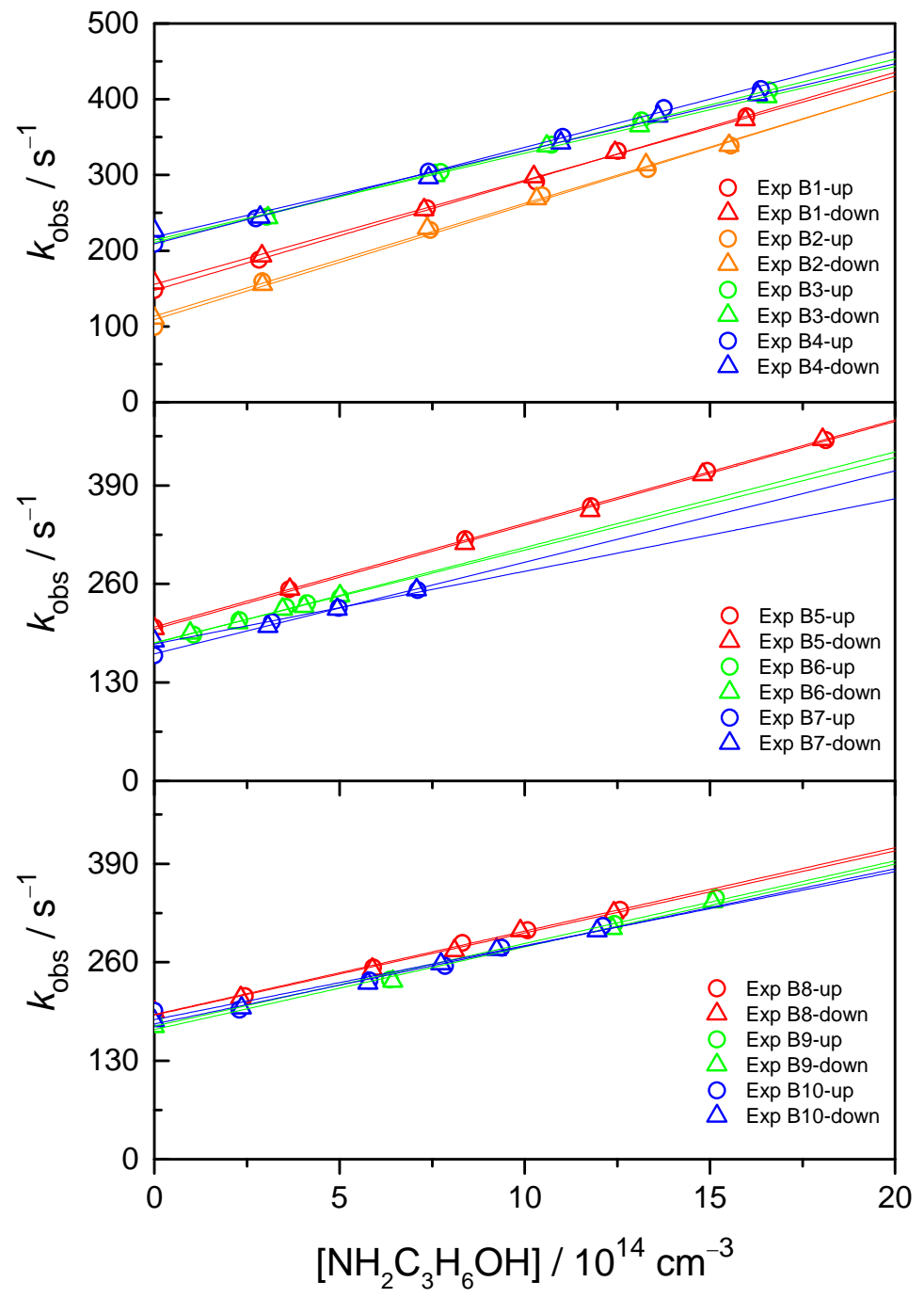

Figure S6. Plot of $k_{\text {obs }}$ of MVKO against $\left[\mathrm{NH}_{2} \mathrm{C}_{3} \mathrm{H}_{6} \mathrm{OH}\right]$. "up" represents scanning $\left[\mathrm{NH}_{2} \mathrm{C}_{3} \mathrm{H}_{6} \mathrm{OH}\right]$ from zero to the maximum, while "down" represents scanning from the maximum to zero. 


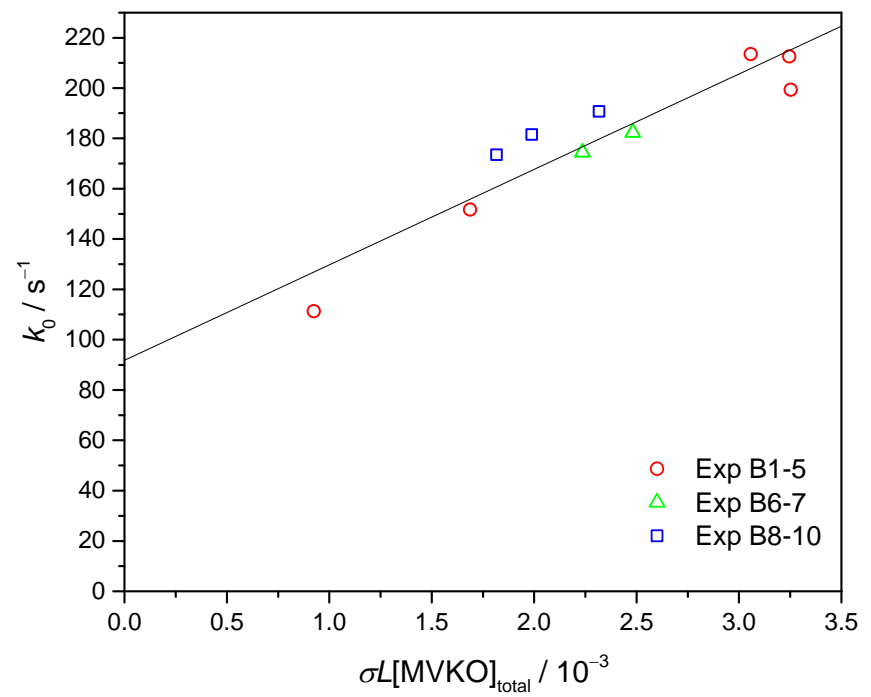

Figure S7. Plot of $k_{0}$ of MVKO against $\sigma L[\mathrm{MVKO}]_{\text {total }}$ at various experiments conditions (Exp $\mathrm{B} 1-\mathrm{B} 10)$. The black line is the linear fit. There is a positive correlation between $k_{0}$ and $\sigma L[\mathrm{MVKO}]_{\text {total }}$ since the major cause of $k_{0}$ is the reactions between MVKO and radicals, which is positive correlated to $[\mathrm{MVKO}]_{\text {total }}$.

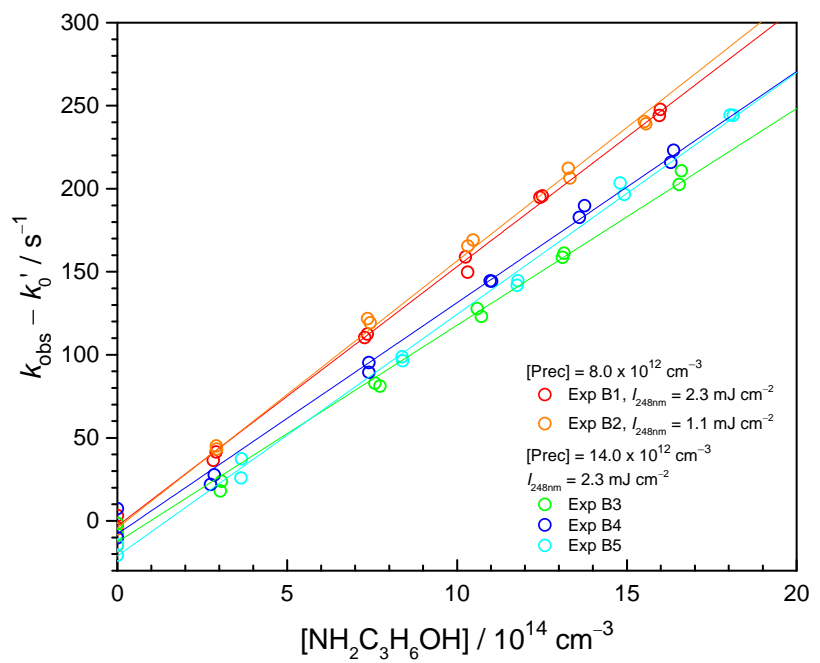

Figure S8. Plot of $k_{\mathrm{obs}}-k_{0}{ }^{\prime}$ of MVKO against $\left[\mathrm{NH}_{2} \mathrm{C}_{3} \mathrm{H}_{6} \mathrm{OH}\right]$ (Exp B1-B5). $k_{0}{ }^{\prime}$ is the corrected $k_{0}$ based on (eq. 9). 


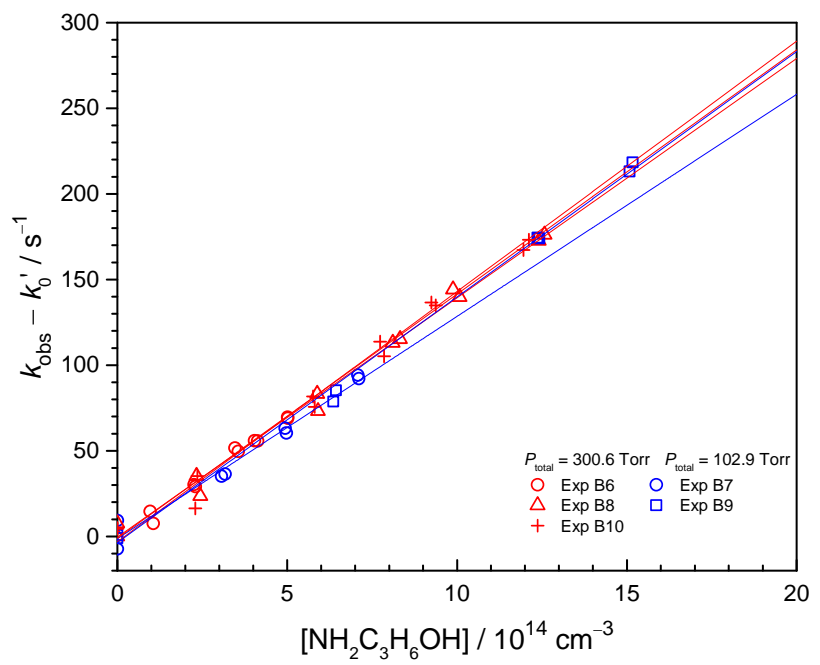

Figure S9. Plot of $k_{\mathrm{obs}}-k_{0}{ }^{\prime}$ of MVKO against $\left[\mathrm{NH}_{2} \mathrm{C}_{3} \mathrm{H}_{6} \mathrm{OH}\right]$ (Exp B6-B10). $k_{0}{ }^{\prime}$ is the corrected $k_{0}$ based on (eq. 9). 


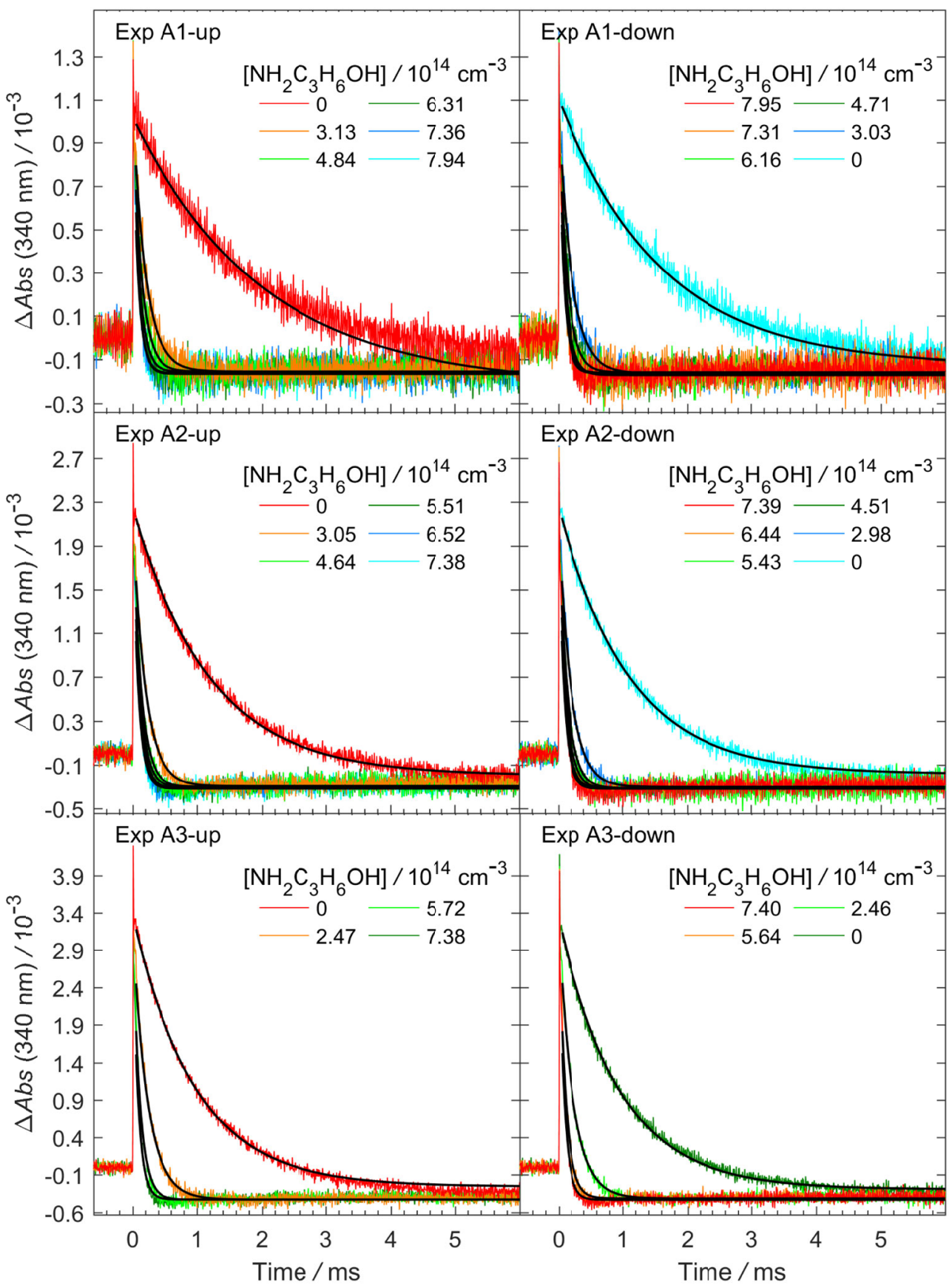

Figure S10. Time traces of absorbance change due to $\left(\mathrm{CH}_{3}\right)_{2} \mathrm{COO}$ at $340 \mathrm{~nm}$ for Exp A1-A3. For each experimental set, $\left[\mathrm{NH}_{2} \mathrm{C}_{3} \mathrm{H}_{6} \mathrm{OH}\right]$ was scanned from 0 to the maximum (labeled as "up") and then from the maximum to 0 (labeled as "down"). The black lines are the fitting of (eq. 1). 


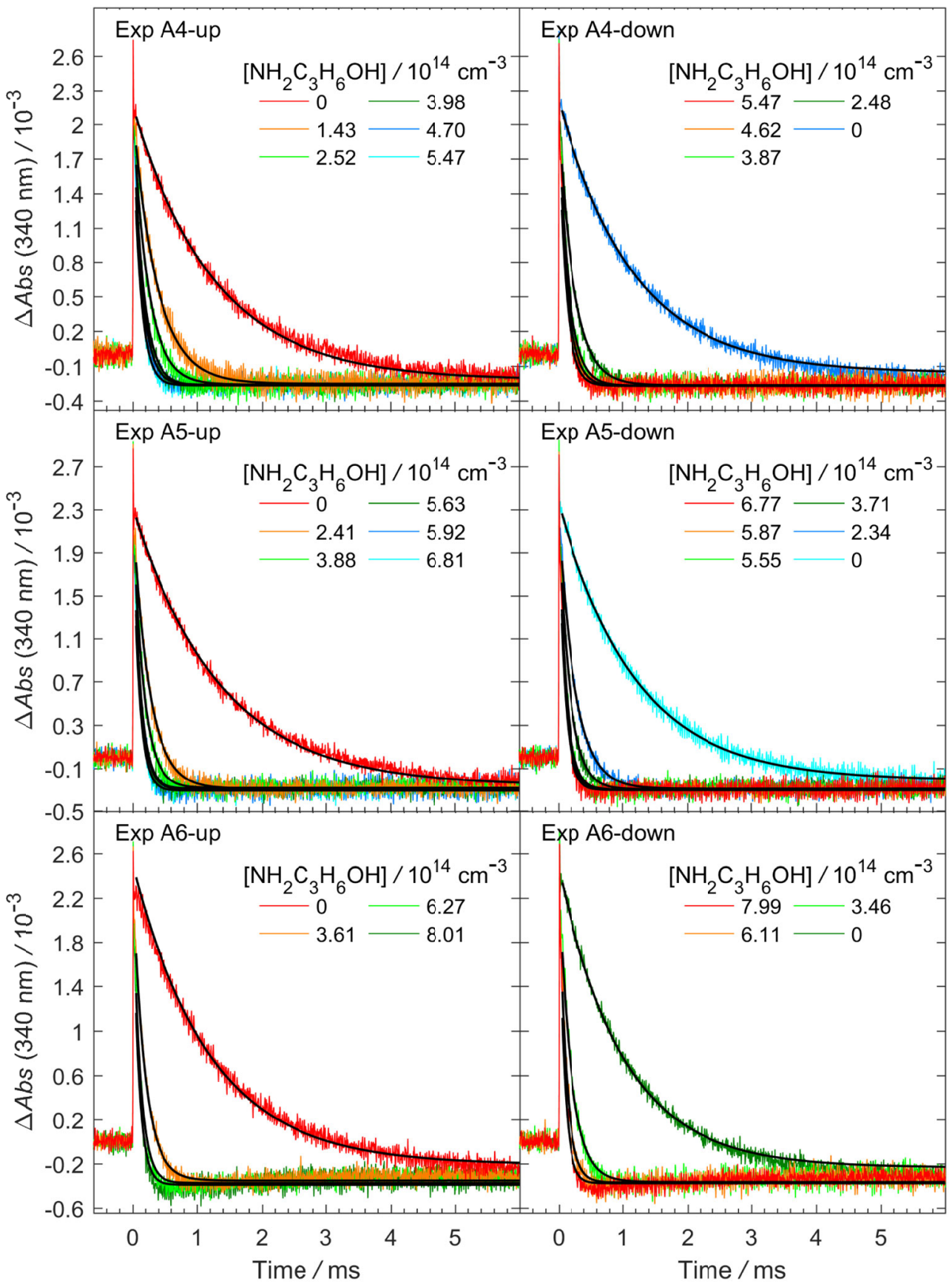

Figure S11. Same as Figure S10, but for Exp A4-A6. 


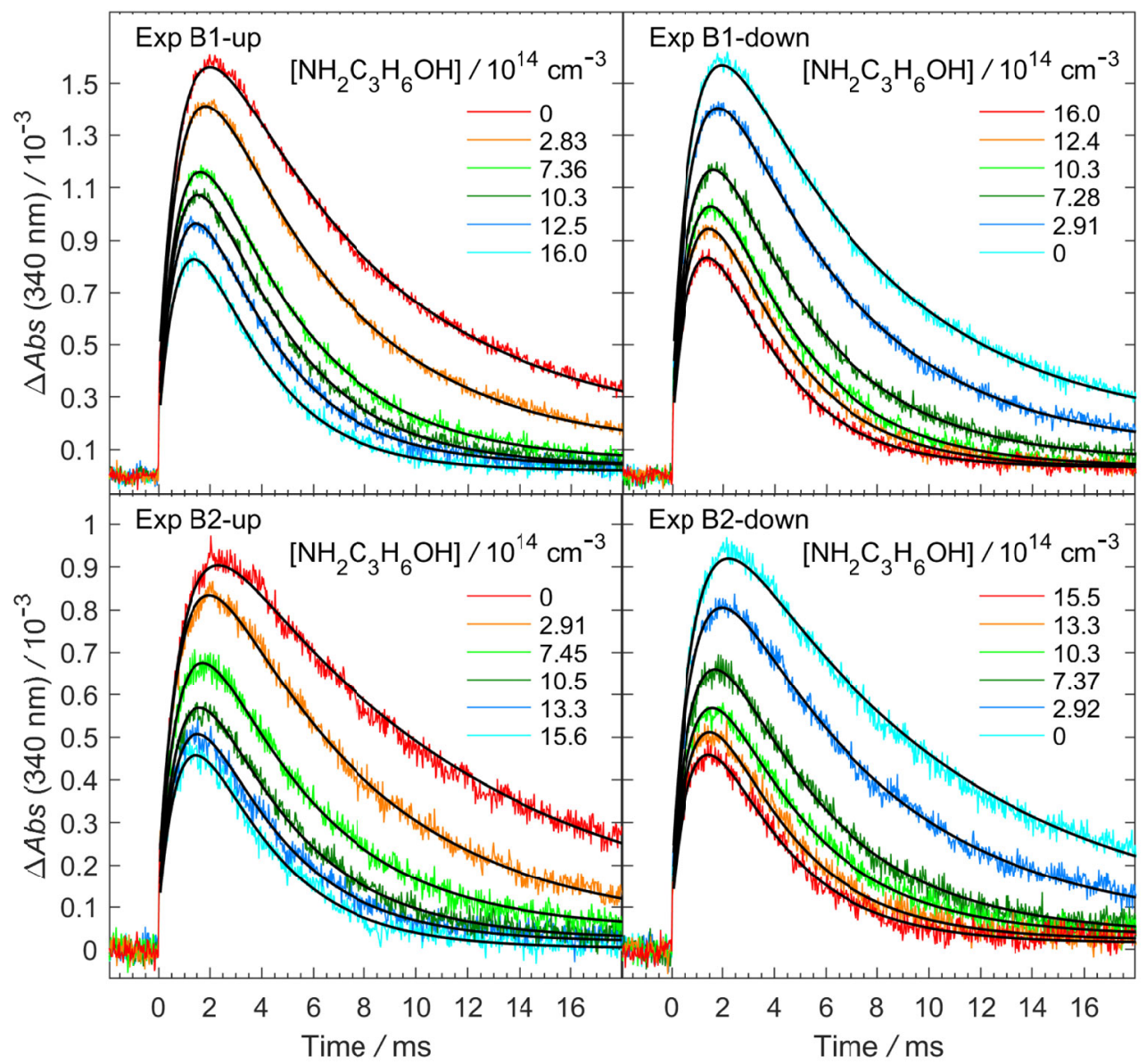

Figure S12. Time traces of absorbance change due to MVKO at $340 \mathrm{~nm}$ for Exp B1-B2. For each experimental set, $\left[\mathrm{NH}_{2} \mathrm{C}_{3} \mathrm{H}_{6} \mathrm{OH}\right]$ was scanned from 0 to the maximum (labeled as "up") and then from the maximum to 0 (labeled as "down"). The black lines are the fitting of (eq. 7). 


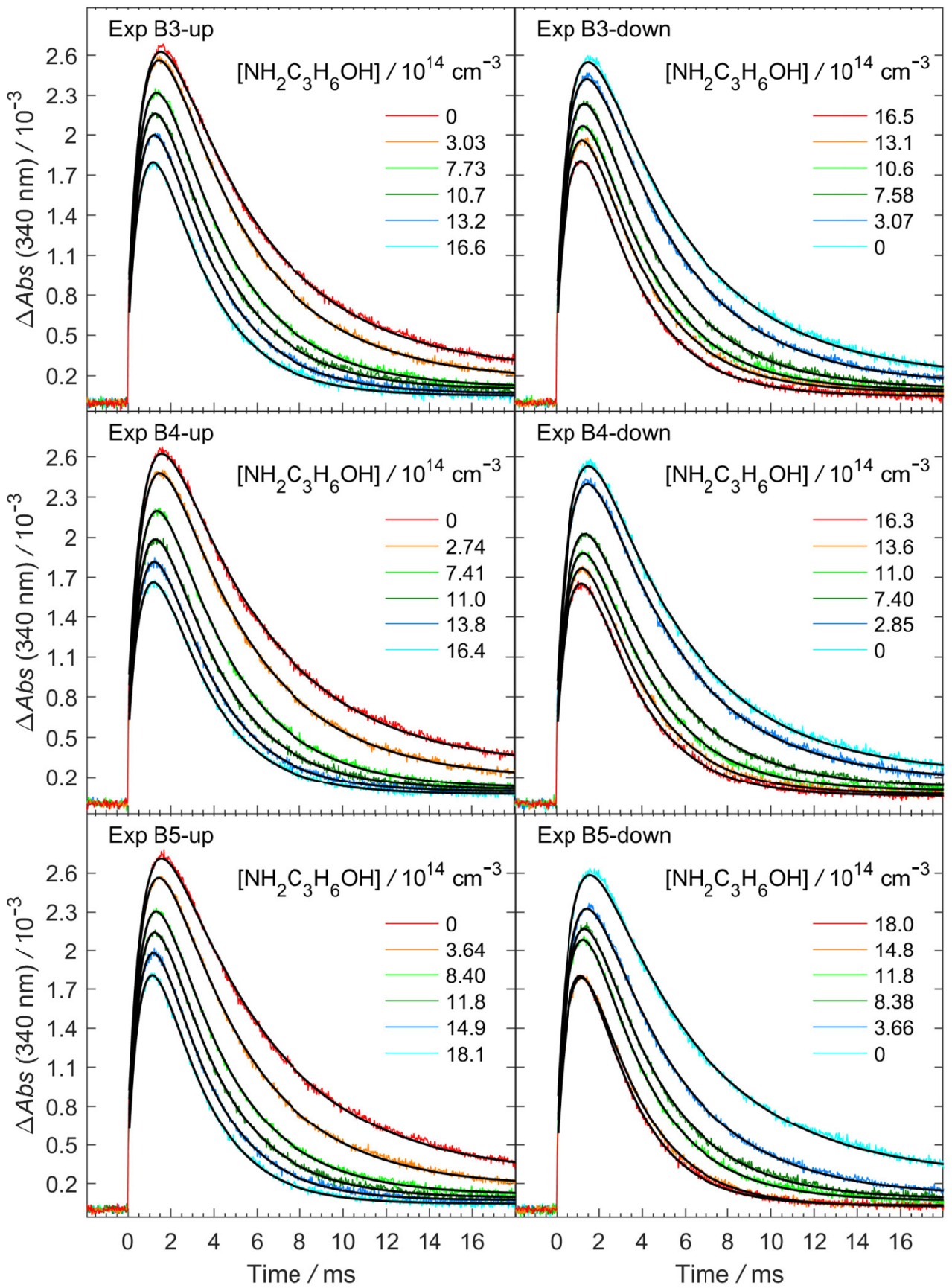

Figure S13. Same as Figure S12, but for Exp B3-B5. 


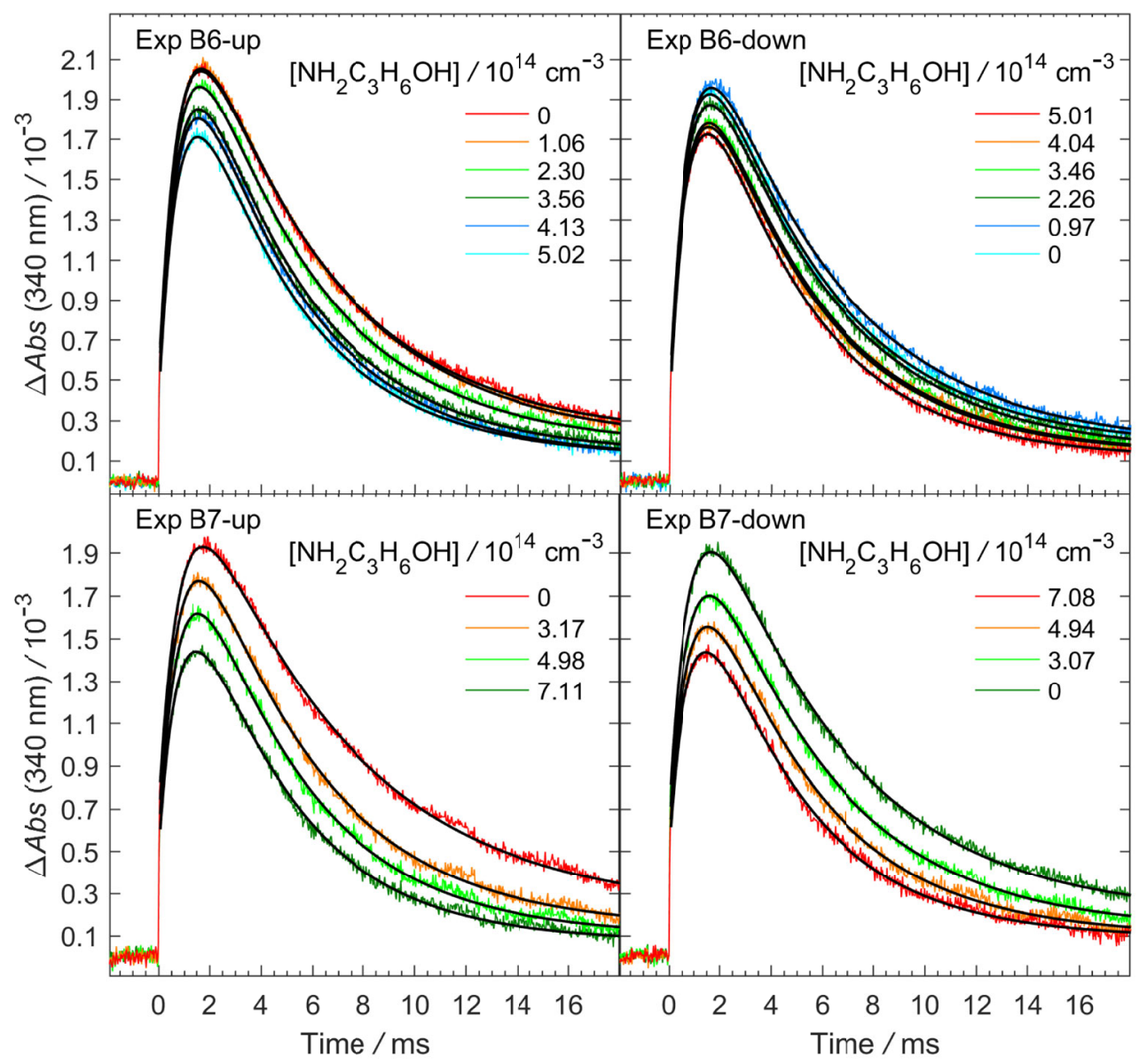

Figure S14. Same as Figure S12, but for Exp B6-B7. 


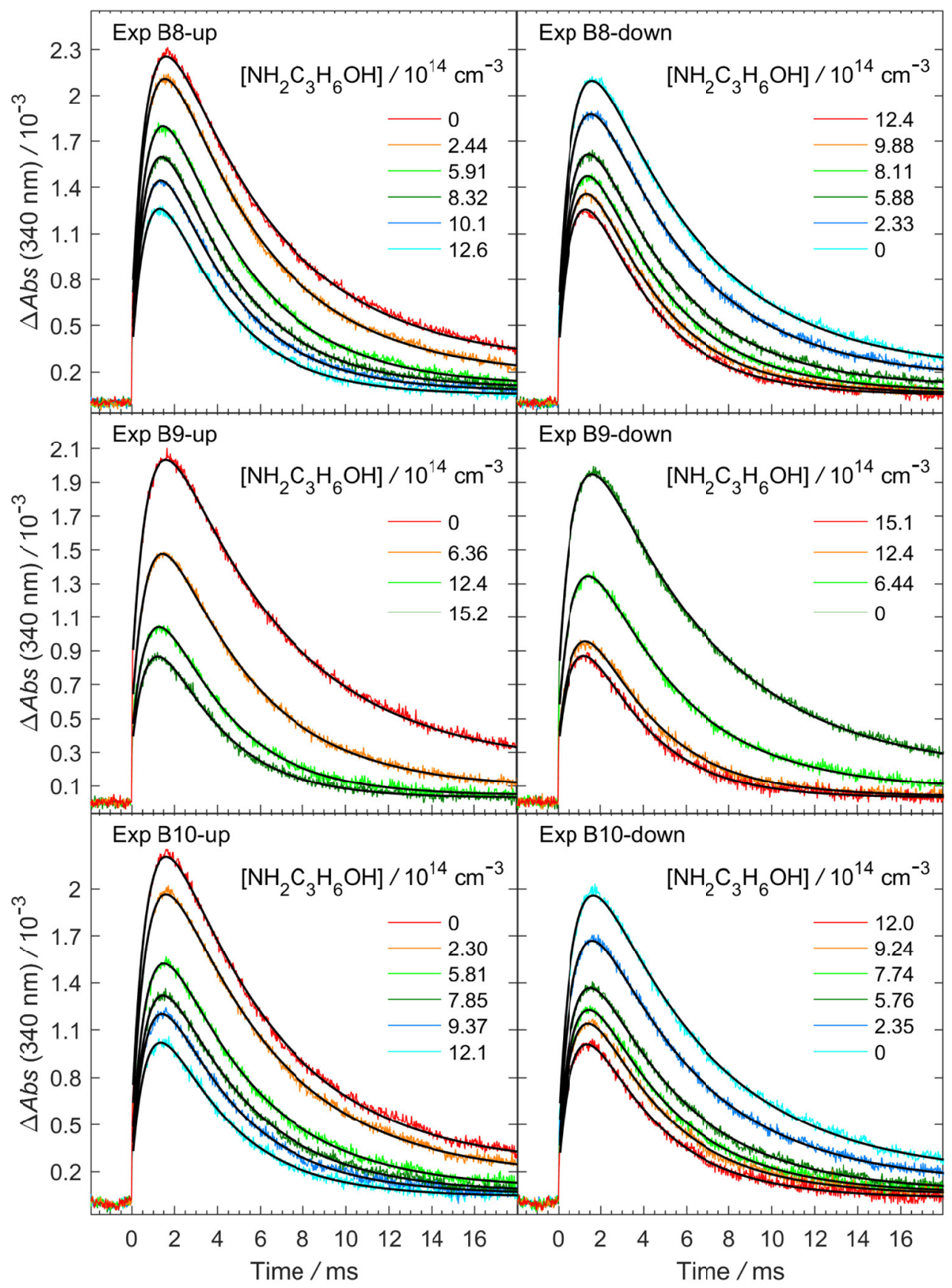

Figure S15. Same as Figure S12, but for Exp B8-B10. 


\section{THEORETICAL DETAILS \\ Evaluation of Quantum Chemistry Methods}

In Table S4, we have presented the zero-point-corrected TS energies calculated with different methods for the reactions of $\mathrm{NH}_{2} \mathrm{C}_{3} \mathrm{H}_{6} \mathrm{OH}$ (AP) with selected CIs. One can notice that compared to the CCSD(T)-F12 results, the B2PLYP-D3BJ energies calculated with the aug-cc-pVTZ basis set are within $1 \mathrm{kcal} \mathrm{mol}^{-1}$ while using a smaller cc-pVTZ basis set results in a larger difference of at most $2.5 \mathrm{kcal} \mathrm{mol}^{-1}$. Nonetheless, these B2PLYP energies are much better than the B3LYP energies, which are higher than the $\operatorname{CCSD}(\mathrm{T})-\mathrm{F} 12$ values by 5 to $8 \mathrm{kcal} \mathrm{mol}^{-1}$. Here one may question the use of B3LYP geometries. Thus, we also performed B2PLYP-D3BJ geometry optimizations for selected CIs. As seen from the values in the parenthesis, using the B2PLYPD3BJ geometries only results in a variation of $0.13 \mathrm{kcal} \mathrm{mol}^{-1}$ at most. So compared to the energy corrections given by B2PLYP, the effect of the geometry optimization is minor.

In Tables S5-S7, we present the decomposition of the TS energies into interaction and strain contributions, calculated by using the CCSD(T)-F12, B2PLYP-D3BJ, and B3LYP methods, respectively. Here we have used the geometries obtained from B3LYP. From the final column, we see that B2PLYP-D3BJ can give electronic energies close to those obtained using the $\operatorname{CCSD}(\mathrm{T})-\mathrm{F} 12$. Furthermore, when one compares the three methods, one can see that the overestimation of the TS energy by B3LYP can be attributed to the weaker interaction contribution. The strain contribution is similar for all three methods. Considering that $\mathrm{CI}+$ $\mathrm{NH}_{2} \mathrm{C}_{3} \mathrm{H}_{6} \mathrm{OH}$ is an early barrier reaction, it also makes sense that the strain contribution is smaller in absolute value than the interaction contribution. At first sight, the increase in the CI strain seems like the main reason that the vinyl substituted CIs have higher TS energies than the alkyl substituted CIs. However, Bickelhaupt and Houk ${ }^{3}$ discussed that one should not just look at the TS contribution since the TS of different CI reactions is at different physically relevant coordinate values.

In our previous study for $\mathrm{CH}_{3} \mathrm{CHOO}+\mathrm{NH}_{2} \mathrm{C}_{3} \mathrm{H}_{6} \mathrm{OH},{ }^{1}$ we have shown that the reaction proceeds through a nucleophilic approach of the amine group followed by an intramolecular $\mathrm{H}$ atom transfer from the $\mathrm{NH}_{2}$ group to the $\mathrm{OH}$ group and finally to the terminal O-atom of the CI. The nucleophilic approach dominates the early part of the reaction path before reaching the TS. Therefore, we choose the distance between the amine group's $\mathrm{N}$-atom and the carbonyl $\mathrm{C}$-atom of the CI as the relevant reaction coordinate. The results in Tables S5-S7 show that B2PLYPD3BJ can give energies similar to those of the time-consuming CCSD(T)-F12 calculations. Therefore we have used the B2PLYP-D3BJ method to calculate the interaction and strain energies as a function of the $\mathrm{C}-\mathrm{N}$ bond distance using the geometries optimized by B3LYP. As shown in Figure S16(a), the potential energy curve along the $\mathrm{CN}$ bond, obtained by CCSD(T)F12 and B2PLYP, for the association of $\mathrm{CH}_{2} \mathrm{OO}$ and $\mathrm{NH}_{2} \mathrm{C}_{3} \mathrm{H}_{6} \mathrm{OH}$ show similar barrierless 
trends. This similarity gives us further confidence in using the energy correction by B2PLYP. In Figure S16(b), we present the potential energy curves for the anti- $\mathrm{CH}_{3} \mathrm{CHOO}$ and anti-transMACRO calculated by B2PLYP. From Figure 9. of the main text, we can see that the main difference between the alkyl and vinyl substituted CIs is due to the difference in the interaction contribution. The strain contribution is fairly similar between $\left(\mathrm{CH}_{3}\right)_{2} \mathrm{COO}$ and MVKO as well as between anti- $\mathrm{CH}_{3} \mathrm{CHOO}$ and MACRO. Similar results are obtained using B3LYP, albeit the absolute value of the interaction energy is smaller.

Table S4. Zero-point energy corrected TS energy, in kcal $\mathrm{mol}^{-1}$, calculated with various quantum chemistry methods at the geometry obtained by B3LYP/6-311+G(2d,2p). The harmonic vibrational frequencies are calculated at $\mathrm{B} 3 \mathrm{LYP} / 6-311+\mathrm{G}(2 \mathrm{~d}, 2 \mathrm{p})$ without scaling. Zero of energy is set as the free reactants of $\mathrm{NH}_{2} \mathrm{C}_{3} \mathrm{H}_{6} \mathrm{OH}+\mathrm{CI}$. The values in parenthesis are those obtained by using geometries optimized with the respective quantum chemistry method.

\begin{tabular}{ccccc}
\hline & $\begin{array}{c}\text { CCSD(T)-F12 } \\
\text { /VTZ-F12 }\end{array}$ & $\begin{array}{c}\text { B2PLYP-D3BJ } \\
\text { /aug-cc-pVTZ }\end{array}$ & $\begin{array}{c}\text { B2PLYP-D3BJ } \\
\text { /cc-pVTZ }\end{array}$ & $\begin{array}{c}\text { B3LYP } \\
\text { (6-311+G(2d,2p) }\end{array}$ \\
\hline amCI & -10.18 & -11.16 & -12.70 & -6.45 \\
\hline atMACRO & -8.27 & -8.58 & $-9.84(-9.75)$ & -1.52 \\
\hline acMACRO & -9.74 & -10.70 & -11.89 & -3.87 \\
\hline smCI & -7.15 & $-8.25(-8.26)$ & $-9.64(-9.65)$ & -3.35 \\
\hline dmCI & -7.32 & -7.65 & $-9.12(-9.15)$ & -0.25 \\
\hline stMVKO & -4.86 & -4.22 & $-5.37(-5.34)$ & 3.85 \\
\hline scMVKO & -6.49 & -6.29 & -7.54 & 2.10
\end{tabular}

Abbreviations: amCI, atMACRO, acMACRO, smCI, dmCI, stMVKO, scMVKO, stand for anti$\mathrm{CH}_{3} \mathrm{CHOO}$, anti-trans-MACRO, anti-cis-MACRO, syn- $\mathrm{CH}_{3} \mathrm{CHOO},\left(\mathrm{CH}_{3}\right)_{2} \mathrm{COO}$, syn-transMVKO, syn-cis-MVKO. 
Table S5. TS electronic energy $E(\mathrm{TS})$ in $\mathrm{kcal} \mathrm{mol}^{-1}$ decomposed into interaction (Int.), and strain contributions of the CI (st. CI) and the aminopropanol (st. AP). All calculations as performed with CCSD(T)-F12/VTZ-F12//B3LYP/6-311+G(2d,2p) method. Zero of energy is set as the free reactant $\mathrm{NH}_{2} \mathrm{C}_{3} \mathrm{H}_{6} \mathrm{OH}+\mathrm{CI}$.

\begin{tabular}{ccccc}
\hline & Int. & st. CI & st. AP & $E(\mathrm{TS})$ \\
\hline amCI & -20.12 & 3.37 & 4.66 & -12.10 \\
\hline atMACRO & -25.66 & 9.32 & 6.12 & -10.22 \\
\hline acMACRO & -24.61 & 6.74 & 6.16 & -11.71 \\
\hline smCI & -21.68 & 7.01 & 5.44 & -9.23 \\
\hline dmCI & -27.52 & 11.41 & 6.70 & -9.41 \\
\hline stMVKO & -29.20 & 15.20 & 7.36 & -6.65 \\
\hline scMVKO & -29.63 & 13.57 & 7.68 & -8.38 \\
\hline
\end{tabular}

Table S6. TS electronic energy $E(\mathrm{TS})$ in $\mathrm{kcal} \mathrm{mol}^{-1}$ decomposed into interaction (Int.), and strain contributions of the CI (st. CI) and the aminopropanol (st. AP). All calculations as performed with B2PLYP-D3BJ/aug-cc-pVTZ//B3LYP/6-311+G(2d,2p). Zero of energy is set as the free reactant $\mathrm{NH}_{2} \mathrm{C}_{3} \mathrm{H}_{6} \mathrm{OH}+\mathrm{CI}$.

\begin{tabular}{ccccc}
\hline & Int. & st. CI & st. AP & $E(\mathrm{TS})$ \\
\hline amCI & -21.60 & 3.83 & 4.69 & -13.08 \\
\hline atMACRO & -26.94 & 10.25 & 6.15 & -10.53 \\
\hline acMACRO & -26.38 & 7.53 & 6.18 & -12.67 \\
\hline smCI & -23.30 & 7.53 & 5.45 & -10.33 \\
\hline dmCI & -28.75 & 12.29 & 6.72 & -9.74 \\
\hline stMVKO & -29.92 & 16.54 & 7.38 & -6.00 \\
\hline scMVKO & -30.62 & 14.74 & 7.69 & -8.18 \\
\hline
\end{tabular}


Table S7. TS electronic energy $E(\mathrm{TS})$ in $\mathrm{kcal} \mathrm{mol}^{-1}$ decomposed into interaction (Int.), and strain contributions of the CI (st. CI) and the aminopropanol (st. AP). All calculations are performed with B3LYP/6-311+G(2d,2p). Zero of energy is set as the free reactant $\mathrm{NH}_{2} \mathrm{C}_{3} \mathrm{H}_{6} \mathrm{OH}+\mathrm{CI}$.

\begin{tabular}{ccccc}
\hline & Int. & st. CI & st. AP & $E(\mathrm{TS})$ \\
\hline amCI & -16.73 & 3.67 & 4.69 & -8.37 \\
\hline atMACRO & -19.74 & 10.06 & 6.21 & -3.47 \\
\hline acMACRO & -19.23 & 7.17 & 6.22 & -5.84 \\
\hline smCI & -18.03 & 7.14 & 5.45 & -5.43 \\
\hline dmCI & -21.33 & 12.22 & 6.77 & -2.34 \\
\hline stMVKO & -21.82 & 16.42 & 7.46 & 2.06 \\
\hline scMVKO & -22.18 & 14.62 & 7.77 & 0.21
\end{tabular}

(a) $\mathrm{CH}_{2} \mathrm{OO}+\mathrm{NH}_{2} \mathrm{C}_{3} \mathrm{H}_{6} \mathrm{OH}$

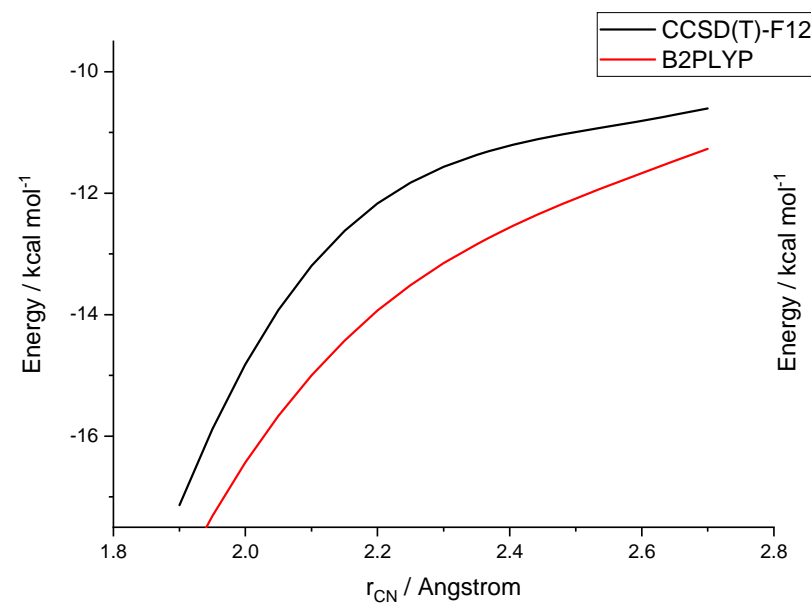

(b) B2PLYP/aug-cc-pVTZ

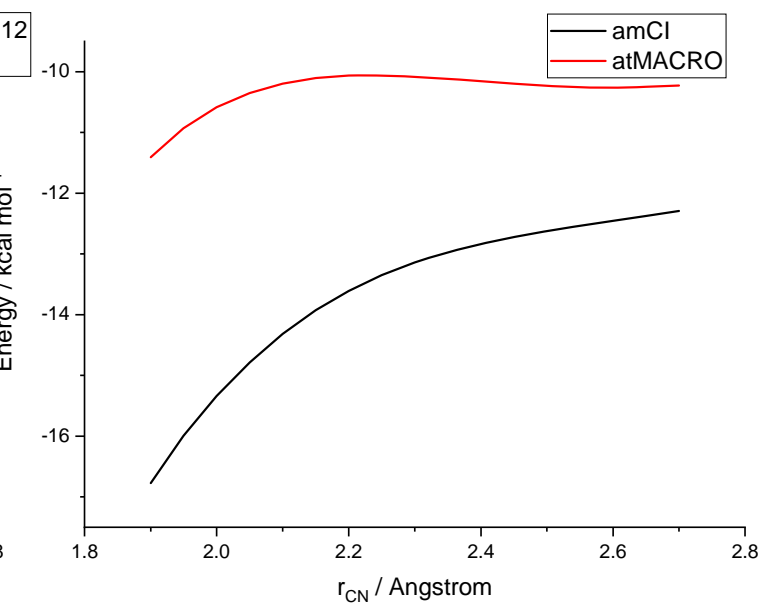

Figure S16. Potential energy curve along the $\mathrm{CN}$ bond distance $r_{\mathrm{CN}}$ (a) for $\mathrm{CH}_{2} \mathrm{OO}+$ $\mathrm{NH}_{2} \mathrm{C}_{3} \mathrm{H}_{6} \mathrm{OH}$ calculated with the CCSD(T)-F12/VTZ-F12 and B2PLYP/aug-cc-pVTZ methods and (b) for anti- $\mathrm{CH}_{3} \mathrm{CHOO}+\mathrm{NH}_{2} \mathrm{C}_{3} \mathrm{H}_{6} \mathrm{OH}$, and anti-trans-MACRO $+\mathrm{NH}_{2} \mathrm{C}_{3} \mathrm{H}_{6} \mathrm{OH}$ calculated with the B2PLYP/aug-cc-pVTZ method. Both use the geometries calculated with B3LYP/6$311+\mathrm{G}(2 \mathrm{~d}, 2 \mathrm{p})$. Infinitely separated reactants are set as the zero of energy. 


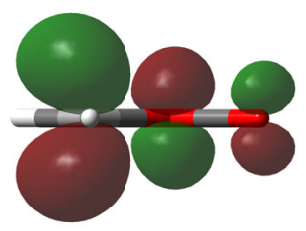

$\mathrm{CH}_{2} \mathrm{OO}$

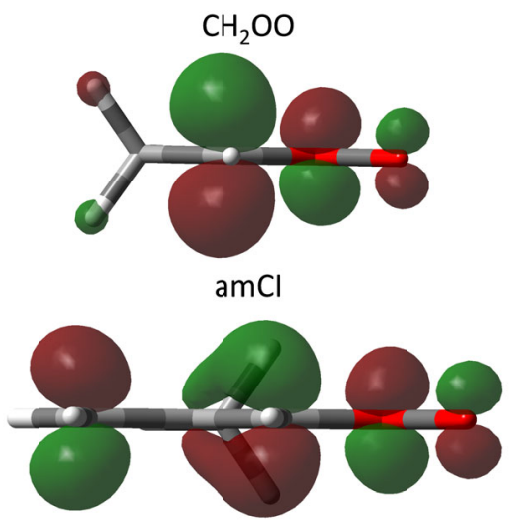

atMACRO

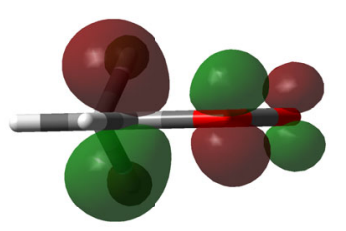

$\mathrm{smCl}$

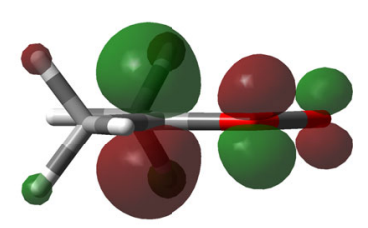

$\mathrm{dmCl}$

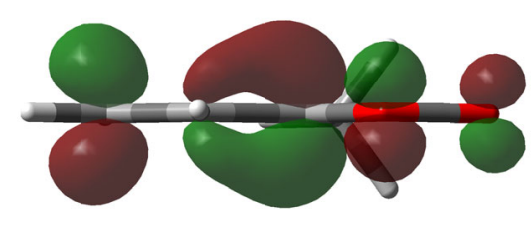

StMVKO

Figure S17. Iso-value plot of the lowest unoccupied molecular orbital (LUMO) of selected CIs at a value of 0.075 , calculated with B2PLYP/aug-cc-pVTZ. For $\mathrm{CH}_{2} \mathrm{OO}$, amCI and atMACRO, the view is from the $s y n$-side. For smCI, dmCI and stMVKO, the view is from the anti-side.

Table S8. The absolute value of the coefficients of the out-of-plane $p$ orbital Gaussian basis sets on the carbonyl C-atom for the LUMO, obtained with B2PLYP/aug-cc-PVTZ

\begin{tabular}{ccccc}
\hline Gaussian Basis $^{a}$ & $\mathrm{CH}_{2} \mathrm{OO}$ & amCI & atMACRO & acMACRO \\
\hline $\mathrm{P}_{\mathrm{a}}$ & 0.22 & 0.25 & 0.19 & 0.19 \\
\hline $\mathrm{P}_{\mathrm{b}}$ & 0.30 & 0.33 & 0.25 & 0.25 \\
\hline $\mathrm{P}_{\mathrm{c}}$ & 0.34 & 0.41 & 0.25 & 0.26 \\
\hline $\mathrm{P}_{\mathrm{d}}$ & 0.28 & 0.40 & 0.14 & 0.12 \\
\hline
\end{tabular}

\begin{tabular}{ccccc}
\hline Gaussian Basis $^{a}$ & smCI & dmCI & stMVKO & scMVKO \\
\hline $\mathrm{P}_{\mathrm{a}}$ & 0.24 & 0.26 & 0.18 & 0.18 \\
\hline $\mathrm{P}_{\mathrm{b}}$ & 0.32 & 0.35 & 0.25 & 0.24 \\
\hline $\mathrm{P}_{\mathrm{c}}$ & 0.34 & 0.38 & 0.22 & 0.20 \\
\hline $\mathrm{P}_{\mathrm{d}}$ & 0.39 & 0.46 & 0.16 & 0.11
\end{tabular}

${ }^{a} \mathrm{P}_{\mathrm{a}-\mathrm{d}}$ corresponds to the aug-cc-pVTZ Gaussian basis sets for the $p$ orbital on the carbonyl Catom of the respective CIs in decreasing order of exponent. 


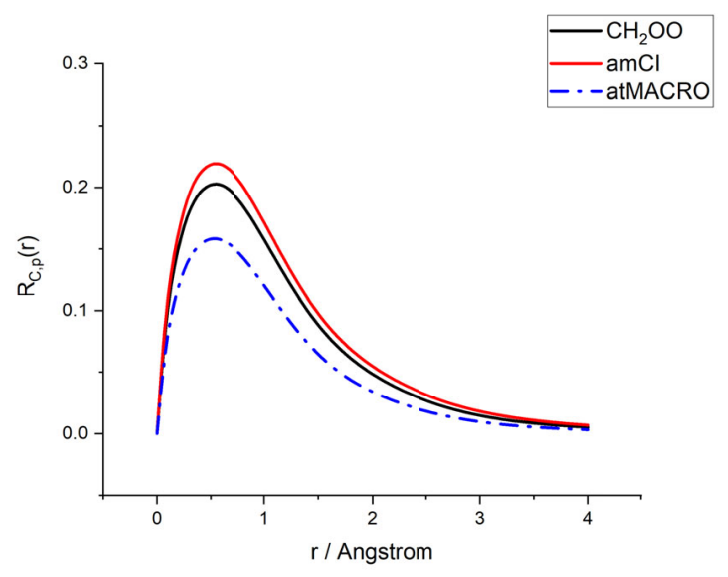

Figure S18. Radial function of the carbonyl C-atom $p$ orbital of the LUMO as a function of the distance. The plot is calculated by using the coefficients given in Table S8 of SI, obtained from

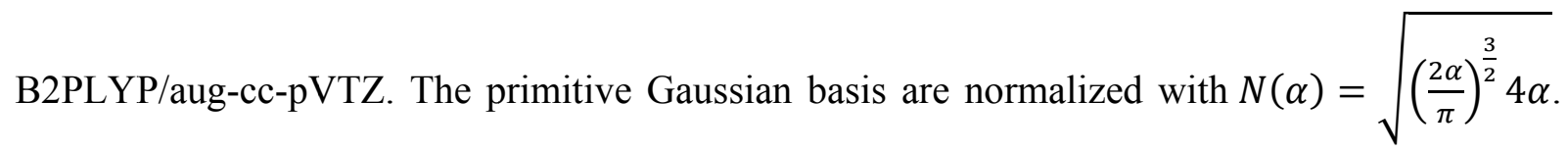
amCI, and atMACRO stands for anti-CH${ }_{3} \mathrm{CHOO}$, and anti-trans-MACRO, respectively. 


\section{Effect of Methyl Rotation}

In Figure S19, we present the potential energy curve along the methyl rotor coordinate for syn- $\mathrm{CH}_{3} \mathrm{CHOO}$ and the TS for the syn- $\mathrm{CH}_{3} \mathrm{CHOO}+\mathrm{NH}_{2} \mathrm{C}_{3} \mathrm{H}_{6} \mathrm{OH}$ reaction. One can see that the rotational barrier is slightly higher at the TS compared to free syn- $\mathrm{CH}_{3} \mathrm{CHOO}$. Using these potential energy curves, we calculated the rate coefficient assuming a hindered rotor for this mode rather than a harmonic oscillator. The room temperature rate coefficient with the hindered rotor was calculated to be $4.06 \times 10^{-11} \mathrm{~cm}^{3} \mathrm{~s}^{-1}$, which is $7 \%$ smaller than the $4.36 \times 10^{-11} \mathrm{~cm}^{3} \mathrm{~s}^{-1}$ obtained using the harmonic oscillator approximation. We note that for the TS geometry, we obtained the curve in Figure S19 by relaxing only the $\mathrm{CH}_{3} \mathrm{CHOO}$ degrees of freedom as we rotated the methyl group. This is because if we allowed all degrees of freedom to relax, the geometry changed to the prereactive complex rather than keeping the TS geometry. To remedy this issue, we instead searched for the $2^{\text {nd }}$ order saddle geometry using B3LYP. At this geometry, we confirmed that the two imaginary frequency vibrational modes correspond to the methyl rotation and our target double $\mathrm{H}$-atom transfer reaction. The barrier obtained this way was 18 $\mathrm{cm}^{-1}$ less than that given in Figure S19, but this does not cause much variation in the rate coefficient. We have performed similar calculations for the other CIs and found that hindered rotation gives variations of 5 to $8 \%$ compared to the harmonic oscillator values.

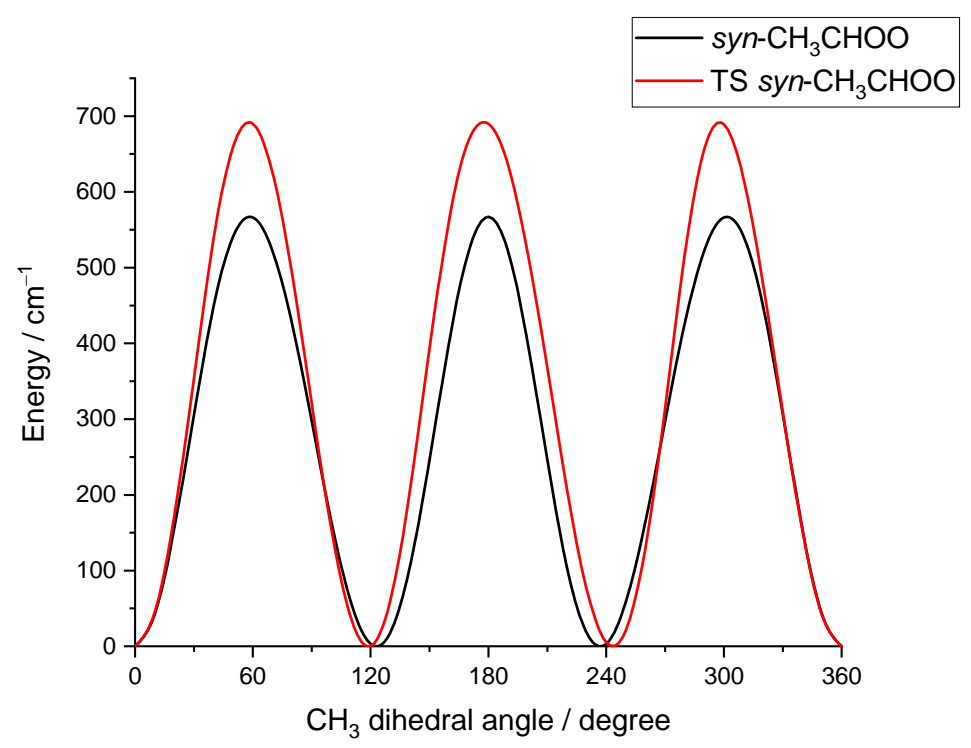

Figure S19. The potential energy curve, in $\mathrm{cm}^{-1}$, for the methyl rotation coordinate for syn$\mathrm{CH}_{3} \mathrm{CHOO}$ and the TS for the syn- $\mathrm{CH}_{3} \mathrm{CHOO}+\mathrm{NH}_{2} \mathrm{C}_{3} \mathrm{H}_{6} \mathrm{OH}$ reaction. 


\section{Hard-Sphere Collision Rate and Dipole Capture Rate}

To estimate the hard-sphere collision rate coefficient, we use the following equation.

$$
k_{\text {coll }}(T)=\pi\left(r_{C I}+r_{A P}\right)^{2} \sqrt{\frac{8 k_{B} T}{\pi \mu}}
$$

Where $r_{C I}$ and $r_{A P}$ are the effective radii of the Criegee intermediate (CI) and the $\mathrm{NH}_{2} \mathrm{C}_{3} \mathrm{H}_{6} \mathrm{OH}$ (AP) molecules, respectively, and $\mu$ is the reduced mass. To obtain the effective radii, we used the electron density obtained by the B3LYP/6-311+G(2d,2p) method with the "volume" keyword in the Gaussian 16 program. In Table S9, we list the parameters used in our calculations as well as the obtained collision rate coefficient. We note that this equation was used by Watson et al. (JPCA, 123, 218-) for reactions between CIs and alcohol, ${ }^{4}$ and Chhantyal-Pun et al. for reactions between CIs and carboxylic acid. ${ }^{5}$

Table S9. Masses, effective radii, and room temperature hard-sphere collision rate coefficient for Criegee intermediate reactions with aminopropanol.

\begin{tabular}{cccccc}
\hline & Mass CI / amu & Mass AP / amu & $r_{C I} / \AA$ & $r_{A P} / \AA$ & $k_{\text {coll }}(298 K) / \mathrm{cm}^{3} \mathrm{~s}^{-1}$ \\
\hline $\mathrm{CH}_{2} \mathrm{OO}$ & 46 & 75 & 2.69 & 3.25 & $5.2 \times 10^{-10}$ \\
\hline amCI & 60 & 75 & 2.94 & 3.25 & $5.2 \times 10^{-10}$ \\
\hline atMACRO & 86 & 75 & 3.26 & 3.25 & $5.3 \times 10^{-10}$ \\
\hline acMACRO & 86 & 75 & 3.42 & 3.25 & $5.5 \times 10^{-10}$ \\
\hline smCI & 60 & 75 & 2.90 & 3.25 & $5.2 \times 10^{-10}$ \\
\hline dmCI & 74 & 75 & 3.31 & 3.25 & $5.6 \times 10^{-10}$ \\
\hline stMVKO & 86 & 75 & 3.33 & 3.25 & $5.4 \times 10^{-10}$ \\
\hline scMVKO & 86 & 75 & 3.17 & 3.25 & $5.1 \times 10^{-10}$ \\
\hline
\end{tabular}

In addition, Georgievskii and Klippenstein have derived an equation for high-pressure capture rate coefficient based on the long range dipole-dipole interaction. ${ }^{6}$

$$
k_{\text {capt }}(T)=\frac{C\left(d_{C I} d_{A P}\right)^{2 / 3}}{\sqrt{\mu} T^{1 / 6}}
$$


where $C$ is a constant, $d_{C I}$ and $d_{A P}$ are the dipole moment values of the CI and AP molecules, and $\mu$ is the reduced mass. This equation was used by Kuwata et al. to predict the rate coefficient between $\mathrm{CH}_{2} \mathrm{OO}$ and $\mathrm{SO}_{2}{ }^{7}$ and Chhantyal-Pun et al. for reactions between CIs and carboxylic acid. $^{5}$

Table S10. Calculated dipole moments of CI and AP using B3LYP/6-311+G(2d,2p) and the room temperature capture rate coefficient.

\begin{tabular}{cccc}
\hline & $d_{C I} /$ Debye & $d_{A P} /$ Debye & $\begin{array}{c}k_{\text {capt }}(298 K) \\
/ \mathrm{cm}^{3} \mathrm{~s}^{-1}\end{array}$ \\
\hline $\mathrm{CH}_{2} \mathrm{OO}$ & 2.69 & 3.25 & $8.9 \times 10^{-10}$ \\
\hline amCI & 2.94 & 3.25 & $9.7 \times 10^{-10}$ \\
\hline atMACRO & 3.26 & 3.25 & $8.9 \times 10^{-10}$ \\
\hline acMACRO & 3.42 & 3.25 & $8.8 \times 10^{-10}$ \\
\hline smCI & 2.90 & 3.25 & $8.7 \times 10^{-10}$ \\
\hline dmCI & 3.31 & 3.25 & $9.1 \times 10^{-10}$ \\
\hline stMVKO & 3.33 & 3.25 & $8.6 \times 10^{-10}$ \\
\hline scMVKO & 3.17 & 3.25 & $8.3 \times 10^{-10}$ \\
\hline
\end{tabular}

The results show that $k_{\text {capt }}(T)$ is slightly larger than the hard-sphere collision rate $k_{\text {coll }}(T)$, while both methods show weak substituent dependence. We note that for the $k_{\text {coll }}(T)$ we have used the sum of the individual radii of $\mathrm{CI}$ and AP $r_{C I}+r_{A P}$, but if we were to use the radii of the prereactive complex CI...AP $r_{C I \ldots A P}(\sim 4.0 \AA)$ instead, then the values will decrease by a factor of 2 or so. We note that the use of dipole moments calculated by CCSD(T)-F12 changes the $k_{\text {capt }}$ by $7 \%$ at most.

\section{Issues Concerning the Overestimation of Rate Coefficient Obtained for Anti-type CIs}

If a bimolecular reaction passes through a prereactive complex, we can have a submerged barrier. In such a situation, the calculated barrier electronic energy is lower than that of the separated reactants. ${ }^{8-9}$ There are situations where the rate coefficients obtained by using TST on these submerged barriers are larger than the collision rates. For the Criegee intermediates, there have been several such reports. ${ }^{4-5,10}$ In the following, we discuss this issue using the reactions of anti- 
and syn- $\mathrm{CH}_{3} \mathrm{CHOO}+\mathrm{NH}_{2} \mathrm{C}_{3} \mathrm{H}_{6} \mathrm{OH}$. As given in Figure $\mathrm{S} 20$, we see that the TS energy is below the reactant energy (defined as zero).

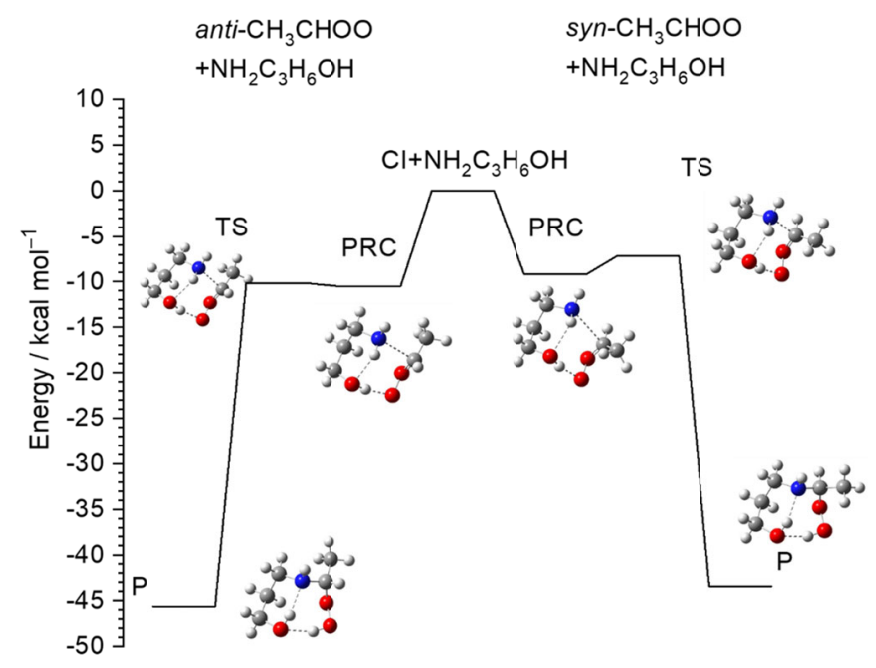

Figure S20. Energy diagram for the anti- and syn- $\mathrm{CH}_{3} \mathrm{CHOO}+\mathrm{NH}_{2} \mathrm{C}_{3} \mathrm{H}_{6} \mathrm{OH}$ reaction. Schematic geometries for the prereactive complex (PRC), transition state (TS) and product (P) are also given. Energies are calculated using CCSD(T)-F12/cc-pVTZ-F12//B3LYP/6$311+\mathrm{G}(2 \mathrm{~d}, 2 \mathrm{p})$, and zero is set as the infinitely separated reactant molecules.

To obtain the bimolecular reaction rate coefficient, we assume thermal equilibrium between the reactants and the prereactive complex. Therefore, the rate coefficient $k(T)$ is obtained from the product of the equilibrium constant $\left(K_{e q}\right)$ between the reactants $\left(\mathrm{CI}+\mathrm{NH}_{2} \mathrm{C}_{3} \mathrm{H}_{6} \mathrm{OH}\right)$ and the prereactive complex $(\mathrm{PRC})$, and the unimolecular rate coefficient of the prereactive complex to form the products $\left(k_{P R C}\right)$ :

$$
\begin{gathered}
\mathrm{CI}+\mathrm{NH}_{2} \mathrm{C}_{3} \mathrm{H}_{6} \mathrm{OH} \rightarrow \text { PRC, } k_{\text {ass }} \\
\mathrm{PRC} \rightarrow \mathrm{CI}+\mathrm{NH}_{2} \mathrm{C}_{3} \mathrm{H}_{6} \mathrm{OH}, k_{\text {dis }} \\
\text { PRC } \rightarrow \text { Products, } k_{\mathrm{PRC}} \\
k(T)=K_{e q}(T) k_{P R C}(T)
\end{gathered}
$$

For this model, one of the assumptions is that the $k_{P R C}(T)$ is much smaller than the rate $\left(k_{d i s}\right)$ of the PRC dissociation back to the reactants, such that we can have an equilibrium population of the PRC. The equilibrium constant can be given by the ratio of the association and dissociation rate coefficients of the PRC as $K_{e q}=\frac{k_{a s s}}{k_{d i s}}$, and therefore, $k_{d i s}=\frac{k_{a s s}}{K_{e q}}$. In Tables S11 and S12, we present the temperature dependence of these values for anti- and syn- $\mathrm{CH}_{3} \mathrm{CHOO}+\mathrm{NH}_{2} \mathrm{C}_{3} \mathrm{H}_{6} \mathrm{OH}$ 
using the energies given in Figure S20. Here we used the gas collision rate given above to estimate the association rate. The results given below will not change much even if we used the dipole capture rate to estimate the association rate. One can see that for the reaction involving anti- $\mathrm{CH}_{3} \mathrm{CHOO}$, the $k_{P R C}$ is larger than the $k_{\text {dis }}$ for all temperatures. Therefore the basic assumption for using TST for the hydrogen atom transfer TS is not valid. As Long et al. have recently mentioned, ${ }^{11}$ these reactions can be considered to depend on both the loose transition state of forming the PRC, and the tight transition state of the hydrogen transfer in the PRC. For the anti-type CIs studied in the present study, the former dominates, and the results obtained using the TST with the tight hydrogen atom transfer TS would overestimate the rate coefficients. For the $s y n$-type CIs, $k_{P R C}$ is smaller than $k_{d i s}$ and the use of the tight TS can give a reasonable estimate for the reaction rate coefficient.

Table S11. Temperature dependence of the equilibrium constant $K_{e q}$ for anti- $\mathrm{CH}_{3} \mathrm{CHOO}+$ $\mathrm{NH}_{2} \mathrm{C}_{3} \mathrm{H}_{6} \mathrm{OH}$ to form the prereactive complex anti- $\mathrm{CH}_{3} \mathrm{CHOO} \ldots \mathrm{NH}_{2} \mathrm{C}_{3} \mathrm{H}_{6} \mathrm{OH}$, association rate $k_{\text {ass }}$ estimated from the collision rate, and dissociation rate $k_{\text {dis }}$, and the unimolecular rate of the prereactive complex $k_{P R C}$.

\begin{tabular}{ccccc}
\hline Temperature $/ \mathrm{K}$ & $K_{e q} / \mathrm{cm}^{3}$ & $k_{\text {ass }} / \mathrm{cm}^{3} \mathrm{~s}^{-1}$ & $k_{\text {dis }} / \mathrm{s}^{-1}$ & $k_{P R C} / \mathrm{s}^{-1}$ \\
\hline 288.15 & $7.2 \times 10^{-20}$ & $5.1 \times 10^{-10}$ & $7.2 \times 10^{9}$ & $1.6 \times 10^{11}$ \\
\hline 293.15 & $5.4 \times 10^{-20}$ & $5.2 \times 10^{-10}$ & $9.7 \times 10^{9}$ & $1.6 \times 10^{11}$ \\
\hline 298.15 & $4.1 \times 10^{-20}$ & $5.2 \times 10^{-10}$ & $1.3 \times 10^{10}$ & $1.6 \times 10^{11}$ \\
\hline 303.15 & $3.1 \times 10^{-20}$ & $5.3 \times 10^{-10}$ & $1.7 \times 10^{10}$ & $1.6 \times 10^{11}$ \\
\hline 308.15 & $2.4 \times 10^{-20}$ & $5.3 \times 10^{-10}$ & $2.2 \times 10^{10}$ & $1.6 \times 10^{11}$ \\
\hline 313.15 & $1.8 \times 10^{-20}$ & $5.4 \times 10^{-10}$ & $2.9 \times 10^{10}$ & $1.6 \times 10^{11}$ \\
\hline 318.15 & $1.4 \times 10^{-20}$ & $5.4 \times 10^{-10}$ & $3.7 \times 10^{10}$ & $1.6 \times 10^{11}$ \\
\hline 323.15 & $1.1 \times 10^{-20}$ & $5.5 \times 10^{-10}$ & $4.8 \times 10^{10}$ & $1.6 \times 10^{11}$ \\
\hline
\end{tabular}


Table S12. Temperature dependence of the equilibrium constant $K_{e q}$ for $s y n-\mathrm{CH}_{3} \mathrm{CHOO}+$ $\mathrm{NH}_{2} \mathrm{C}_{3} \mathrm{H}_{6} \mathrm{OH}$ to form the prereactive complex syn- $\mathrm{CH}_{3} \mathrm{CHOO} \ldots \mathrm{NH}_{2} \mathrm{C}_{3} \mathrm{H}_{6} \mathrm{OH}$, association rate $k_{\text {ass }}$ estimated from the collision rate, and dissociation rate $k_{d i s}$, and the unimolecular rate of the prereactive complex $k_{P R C}$.

\begin{tabular}{ccccc}
\hline Temperature $/ \mathrm{K}$ & $K_{e q} / \mathrm{cm}^{3}$ & $k_{\text {ass }} / \mathrm{cm}^{3} \mathrm{~s}^{-1}$ & $k_{\text {dis }} / \mathrm{s}^{-1}$ & $k_{P R C} / \mathrm{s}^{-1}$ \\
\hline 288.15 & $4.6 \times 10^{-21}$ & $5.1 \times 10^{-10}$ & $1.1 \times 10^{11}$ & $7.0 \times 10^{9}$ \\
\hline 293.15 & $3.6 \times 10^{-21}$ & $5.1 \times 10^{-10}$ & $1.4 \times 10^{11}$ & $7.4 \times 10^{9}$ \\
\hline 298.15 & $2.8 \times 10^{-21}$ & $5.2 \times 10^{-10}$ & $1.8 \times 10^{11}$ & $7.7 \times 10^{9}$ \\
\hline 303.15 & $2.2 \times 10^{-21}$ & $5.2 \times 10^{-10}$ & $2.3 \times 10^{11}$ & $8.1 \times 10^{9}$ \\
\hline 308.15 & $1.8 \times 10^{-21}$ & $5.3 \times 10^{-10}$ & $2.9 \times 10^{11}$ & $8.4 \times 10^{9}$ \\
\hline 313.15 & $1.4 \times 10^{-21}$ & $5.3 \times 10^{-10}$ & $3.7 \times 10^{11}$ & $8.8 \times 10^{9}$ \\
\hline 318.15 & $1.2 \times 10^{-21}$ & $5.3 \times 10^{-10}$ & $4.6 \times 10^{11}$ & $9.1 \times 10^{9}$ \\
\hline 323.15 & $9.6 \times 10^{-22}$ & $5.4 \times 10^{-10}$ & $5.6 \times 10^{11}$ & $9.5 \times 10^{9}$ \\
\hline
\end{tabular}

\section{Comparison to the Reaction with Water Vapor}

We calculated TS energies for the reaction of $\left(\mathrm{CH}_{3}\right)_{2} \mathrm{COO}$ and syn-trans-MVKO with 1 and 2 water molecules. In Table S14, we compare the rate coefficients for the $\mathrm{CI}+\mathrm{H}_{2} \mathrm{O}$ and $\mathrm{CI}+2 \mathrm{H}_{2} \mathrm{O}$ reactions using these barrier energies with literature values. We can see that the calculated values are all below the available experimental upper limits. In addition, we can see that the B2PLYP-D3BJ results are within an order of magnitude compared to the CCSD(T)-F12 and the literature values of Vereecken et al. ${ }^{12}$ On the other hand, the rate coefficients calculated by B3LYP are a few orders of magnitude smaller, which is consistent with the higher barrier energies seen in Figure 11 of the main text. 
Table S13. Zero-point energy corrected TS energy, in kcal mol ${ }^{-1}$, calculated with various quantum chemistry methods at the geometry obtained by B3LYP/6-311+G(2d,2p) for the reactions of $\left(\mathrm{CH}_{3}\right)_{2} \mathrm{COO}$ and syn-trans-MVKO with 1 or $2 \mathrm{H}_{2} \mathrm{O}$ molecules. The harmonic vibrational frequencies are calculated at B3LYP/6-311+G(2d,2p) without scaling. Zero of energy is set as the free reactants of 1 or $2 \mathrm{H}_{2} \mathrm{O}+\mathrm{CI}$.

\begin{tabular}{cccc}
\hline & $\mathrm{CCSD}(\mathrm{T})-\mathrm{F} 12 \mathrm{~B} 2 \mathrm{PLYP}-\mathrm{D} 3 \mathrm{BJ}$ & $\mathrm{B} 3 \mathrm{LYP}$ \\
& $/ \mathrm{VTZ}-\mathrm{F} 12$ & /aug-cc-pVTZ & /6-311+G(2d,2p) \\
\hline$\left(\mathrm{CH}_{3}\right)_{2} \mathrm{COO}+\mathrm{H}_{2} \mathrm{O} 1 \mathrm{a}$ & 5.87 & 5.34 & 8.44 \\
\hline$\left(\mathrm{CH}_{3}\right)_{2} \mathrm{COO}+\mathrm{H}_{2} \mathrm{O} 1 \mathrm{~b}$ & 4.79 & 4.24 & 7.23 \\
\hline$\left(\mathrm{CH}_{3}\right)_{2} \mathrm{COO}+2 \mathrm{H}_{2} \mathrm{O} 2 \mathrm{a}$ & -6.79 & -8.54 & -4.13 \\
\hline$\left(\mathrm{CH}_{3}\right)_{2} \mathrm{COO}+2 \mathrm{H}_{2} \mathrm{O} 2 \mathrm{~d}$ & -7.00 & -8.75 & -4.45 \\
\hline$\left(\mathrm{CH}_{3}\right)_{2} \mathrm{COO}+2 \mathrm{H}_{2} \mathrm{O} 2 \mathrm{c}$ & -5.42 & -7.17 & -2.79 \\
\hline$\left(\mathrm{CH}_{3}\right)_{2} \mathrm{COO}+2 \mathrm{H}_{2} \mathrm{O} 2 \mathrm{~d}$ & -7.05 & -8.78 & -4.29 \\
\hline syn-trans-MVKO$+\mathrm{H}_{2} \mathrm{O} 1 \mathrm{a}$ & 9.56 & 9.28 & 12.41 \\
\hline syn-trans-MVKO$+\mathrm{H}_{2} \mathrm{O} 1 \mathrm{~b}$ & 8.03 & 7.64 & 10.61 \\
\hline syn-trans-MVKO$+2 \mathrm{H}_{2} \mathrm{O} 2 \mathrm{a}$ & -2.36 & -3.88 & 0.46 \\
\hline syn-trans-MVKO$+2 \mathrm{H}_{2} \mathrm{O} 2 \mathrm{~b}$ & -2.34 & -3.81 & 0.53 \\
\hline syn-trans-MVKO$+2 \mathrm{H}_{2} \mathrm{O} 2 \mathrm{c}$ & -0.72 & -2.19 & 2.22 \\
\hline syn-trans-MVKO$+2 \mathrm{H}_{2} \mathrm{O} 2 \mathrm{~d}$ & -2.47 & -3.96 & 0.46 \\
\hline
\end{tabular}


Table S14. Comparison of rate coefficients of $\mathrm{CI}+\mathrm{H}_{2} \mathrm{O}\left(\right.$ in $\left.\mathrm{cm}^{3} \mathrm{~s}^{-1}\right)$ and $\mathrm{CI}+2 \mathrm{H}_{2} \mathrm{O}\left(\right.$ in $\left.\mathrm{cm}^{6} \mathrm{~s}^{-1}\right)$ calculated using different quantum chemistry methods and available computational literature values by Vereecken et al. ${ }^{12}$ and the experimental upper limit. ${ }^{13-14}$

\begin{tabular}{c|c|cccc}
\hline & Experimental & \multicolumn{4}{|c}{ B2PLYP- } \\
upper limit & $\begin{array}{c}\text { CCSD(T)-F12 } \\
\text { /VTZ-F12 }\end{array}$ & $\begin{array}{c}\text { D3BJ } \\
\text { /aug-cc- } \\
\text { pVTZ }\end{array}$ & $\begin{array}{c}\text { B3LYP } \\
/ 611+\mathrm{G}(2 \mathrm{~d}, 2 \mathrm{p})\end{array}$ & $\begin{array}{c}\text { Vereecken } \\
\text { et al. }^{12}\end{array}$ \\
\hline $\begin{array}{c}\text { syn-trans- } \\
\left(\mathrm{CH}_{3}\right)_{2} \mathrm{COO}+\mathrm{H}_{2} \mathrm{O}\end{array}$ & $1.50 \times 10^{-16}$ & $8.21 \times 10^{-18}$ & $2.07 \times 10^{-17}$ & $1.30 \times 10^{-19}$ & $7.50 \times 10^{-18}$ \\
\hline $\begin{array}{c}\mathrm{MVKO}+\mathrm{H}_{2} \mathrm{O} \\
(\mathrm{CH})_{2} \mathrm{COO}+2 \mathrm{H}_{2} \mathrm{O}^{\mathrm{a}}\end{array}$ & $2.00 \times 10^{-17}$ & $3.27 \times 10^{-20}$ & $6.24 \times 10^{-20}$ & $4.10 \times 10^{-22}$ & $8.10 \times 10^{-20}$ \\
\hline $\begin{array}{c}\text { syn-trans- } \\
\mathrm{MVKO}+2 \mathrm{H}_{2} \mathrm{O}^{\mathrm{a}}\end{array}$ & $6.18 \times 10^{-35}$ & $3.46 \times 10^{-35}$ & $6.55 \times 10^{-34}$ & $3.95 \times 10^{-37}$ & $3.71 \times 10^{-35}$ \\
\hline
\end{tabular}

${ }^{\text {a }}$ Obtained using the reported reaction rate coefficient for $\mathrm{CI}+\left(\mathrm{H}_{2} \mathrm{O}\right)_{2}$ and the water dimer equilibrium constant value $2.06 \times 10^{-21} \mathrm{~cm}^{3}$ reported by Ruscic. ${ }^{15}$ 


\section{XYZ Geometries}

Below are the optimized geometries for the prereactive complex, transition state, and product, obtained at B3LYP/6-311+G(2d,2p). Unit: Angstrom.

\section{anti- $\mathrm{CH}_{3} \mathrm{CHOO}+\mathrm{NH}_{2} \mathrm{C}_{3} \mathrm{H}_{6} \mathrm{OH}$}

\begin{tabular}{|c|c|c|c|c|c|c|c|}
\hline & Prereactive con & nplex & & Transition Stat & & Product & \\
\hline $\mathrm{C}$ & -1.9790 .359 & 0.202 & $\mathrm{C}$ & -1.7770 .171 & $-0.392 \mathrm{C}$ & $-1.515-0.111$ & 0.468 \\
\hline $\mathrm{H}$ & -1.8430 .576 & 1.254 & $\mathrm{H}$ & $-1.802-0.020$ & $-1.457 \mathrm{H}$ & -1.9910 .271 & 1.373 \\
\hline $\mathrm{O}$ & -1.4111 .114 & -0.619 & $\mathrm{O}$ & $-1.449-0.792$ & $0.353 \mathrm{O}$ & -1.2550 .983 & -0.401 \\
\hline $\mathrm{O}$ & -0.6022 .136 & -0.089 & $\mathrm{O}$ & $-0.888-1.915$ & $-0.332 \mathrm{O}$ & -0.7142 .087 & 0.361 \\
\hline $\mathrm{C}$ & $-2.920-0.663$ & -0.304 & $\mathrm{C}$ & $-2.521 \quad 1.297$ & $0.231 \mathrm{C}$ & $-2.501-0.981$ & -0.313 \\
\hline $\mathrm{H}$ & $-2.739-1.610$ & 0.201 & $\mathrm{H}$ & -2.3812 .212 & $-0.338 \mathrm{H}$ & $-2.703-1.902$ & 0.234 \\
\hline $\mathrm{H}$ & $-3.943-0.352$ & -0.073 & $\mathrm{H}$ & -3.5881 .056 & $0.226 \mathrm{H}$ & $-3.436-0.440$ & -0.445 \\
\hline $\mathrm{H}$ & $-2.822-0.787$ & -1.379 & $\mathrm{H}$ & -2.2101 .449 & $1.262 \mathrm{H}$ & $-2.118-1.237$ & -1.299 \\
\hline $\mathrm{N}$ & $\begin{array}{lll}0.068 & -1.299\end{array}$ & 1.035 & $\mathrm{~N}$ & $0.238 \quad 1.196$ & $-0.897 \mathrm{~N}$ & $-0.276-0.761$ & 0.909 \\
\hline $\mathrm{H}$ & $\begin{array}{ll}0.535 & -0.536\end{array}$ & 1.519 & $\mathrm{H}$ & $0.661 \quad 0.433$ & $-1.423 \mathrm{H}$ & $1.217 \quad 0.530$ & 1.151 \\
\hline $\mathrm{H}$ & $-0.172-2.003$ & 1.724 & $\mathrm{H}$ & $0.096 \quad 1.985$ & $-1.518 \mathrm{H}$ & $-0.472-1.290$ & 1.749 \\
\hline $\mathrm{C}$ & $\begin{array}{lll}1.021 & -1.859\end{array}$ & 0.053 & $\mathrm{C}$ & $1.157 \quad 1.556$ & $0.206 \mathrm{C}$ & $0.471-1.593$ & -0.059 \\
\hline $\mathrm{H}$ & $0.512-2.655$ & -0.495 & $\mathrm{H}$ & $0.661 \quad 2.297$ & $0.835 \mathrm{H}$ & $-0.189-2.236$ & -0.649 \\
\hline $\mathrm{H}$ & $1.889-2.318$ & 0.545 & $\mathrm{H}$ & $2.064 \quad 2.029$ & $-0.188 \mathrm{H}$ & $1.107-2.257$ & 0.530 \\
\hline $\mathrm{C}$ & $\begin{array}{ll}1.512 & -0.799\end{array}$ & -0.933 & $\mathrm{C}$ & $1.546 \quad 0.339$ & $1.049 \mathrm{C}$ & $1.356-0.766$ & -1.000 \\
\hline $\mathrm{H}$ & $\begin{array}{lll}2.095 & -1.297\end{array}$ & -1.713 & $\mathrm{H}$ & $2.158 \quad 0.690$ & $1.884 \mathrm{H}$ & $1.853-1.453$ & -1.692 \\
\hline $\mathrm{H}$ & $0.657-0.335$ & -1.428 & $\mathrm{H}$ & $0.653-0.112$ & $1.482 \mathrm{H}$ & $0.737-0.098$ & -1.599 \\
\hline $\mathrm{C}$ & $2.393 \quad 0.289$ & -0.311 & $\mathrm{C}$ & $2.340-0.732$ & $0.293 \mathrm{C}$ & $2.429 \quad 0.045$ & -0.277 \\
\hline $\mathrm{H}$ & $2.724 \quad 0.976$ & -1.097 & $\mathrm{H}$ & $2.584-1.546$ & $0.984 \mathrm{H}$ & $3.034 \quad 0.600$ & -0.993 \\
\hline $\mathrm{H}$ & $3.289-0.165$ & 0.120 & $\mathrm{H}$ & $3.286-0.313$ & $-0.059 \mathrm{H}$ & $3.102-0.628$ & 0.269 \\
\hline $\mathrm{O}$ & $1.770 \quad 1.003$ & 0.748 & $\mathrm{O}$ & $1.677-1.232$ & $-0.859 \mathrm{O}$ & $1.885 \quad 1.011$ & 0.629 \\
\hline $\mathrm{H}$ & $0.978 \quad 1.469$ & 0.398 & $\mathrm{H}$ & $\begin{array}{lll}0.787 & -1.585\end{array}$ & $-0.600 \mathrm{H}$ & $0.248 \quad 1.945$ & 0.258 \\
\hline
\end{tabular}




\section{anti-trans-MACRO $+\mathrm{NH}_{2} \mathrm{C}_{3} \mathrm{H}_{6} \mathrm{OH}$}

\begin{tabular}{|c|c|c|c|c|c|c|c|c|c|c|}
\hline \multirow[b]{2}{*}{$\mathrm{C}$} & \multicolumn{3}{|c|}{ Prereactive complex } & \multicolumn{4}{|c|}{ Transition State } & \multicolumn{3}{|c|}{ Product } \\
\hline & -1.4580 .677 & -0.209 & $\mathrm{C}$ & -1.209 & 0.319 & -0.265 & & -1.071 & 0.146 & 0.014 \\
\hline $\mathrm{O}$ & -0.6171 .104 & -1.047 & $\mathrm{O}$ & -0.469 & 0.872 & -1.160 & $\mathrm{O}$ & -0.481 & 0.925 & -1.015 \\
\hline $\mathrm{O}$ & $0.259 \quad 2.096$ & -0.618 & $\mathrm{O}$ & 0.318 & 1.953 & -0.615 & $\mathrm{O}$ & 0.111 & 2.110 & -0.437 \\
\hline $\mathrm{H}$ & -1.4441 .111 & 0.782 & $\mathrm{H}$ & -1.473 & 0.939 & 0.584 & $\mathrm{H}$ & -1.617 & 0.812 & 0.684 \\
\hline $\mathrm{C}$ & $-2.440-0.291$ & -0.631 & $\mathrm{C}$ & -2.198 & -0.665 & -0.758 & $\mathrm{C}$ & -2.066 & -0.782 & -0.686 \\
\hline $\mathrm{C}$ & $-3.391-0.621$ & 0.256 & $\mathrm{C}$ & -3.257 & -0.933 & 0.008 & $\mathrm{C}$ & -3.132 & -1.197 & -0.008 \\
\hline $\mathrm{C}$ & $-2.357-0.852$ & -2.022 & $\mathrm{C}$ & -1.979 & -1.270 & -2.117 & $\mathrm{C}$ & -1.820 & -1.178 & -2.118 \\
\hline $\mathrm{H}$ & $-2.401-0.058$ & -2.768 & $\mathrm{H}$ & -1.944 & -0.493 & -2.880 & $\mathrm{H}$ & -1.848 & -0.302 & -2.766 \\
\hline $\mathrm{H}$ & $-1.411-1.375$ & -2.170 & $\mathrm{H}$ & -1.028 & -1.801 & -2.170 & $\mathrm{H}$ & -0.838 & -1.633 & -2.257 \\
\hline $\mathrm{H}$ & $-3.173-1.548$ & -2.204 & $\mathrm{H}$ & -2.780 & -1.966 & -2.360 & $\mathrm{H}$ & -2.578 & -1.884 & -2.453 \\
\hline $\mathrm{H}$ & $-3.406-0.197$ & 1.251 & $\mathrm{H}$ & -3.401 & -0.454 & 0.967 & $\mathrm{H}$ & -3.327 & -0.874 & 1.007 \\
\hline $\mathrm{H}$ & $-4.173-1.324$ & 0.008 & $\mathrm{H}$ & -4.020 & -1.630 & -0.310 & $\mathrm{H}$ & -3.853 & -1.873 & -0.448 \\
\hline $\mathrm{N}$ & $0.334 \quad-1.023$ & 1.522 & $\mathrm{~N}$ & 0.030 & -0.739 & 0.910 & $\mathrm{~N}$ & -0.054 & -0.509 & 0.850 \\
\hline $\mathrm{H}$ & $\begin{array}{lll}0.732 & -0.188\end{array}$ & 1.939 & $\mathrm{H}$ & 0.617 & -0.003 & 1.315 & $\mathrm{H}$ & 1.585 & 0.590 & 1.077 \\
\hline $\mathrm{H}$ & $-0.129-1.549$ & 2.254 & $\mathrm{H}$ & -0.563 & -1.148 & 1.623 & $\mathrm{H}$ & -0.494 & -0.771 & 1.723 \\
\hline $\mathrm{C}$ & $1.433-1.820$ & 0.946 & $\mathrm{C}$ & 0.926 & -1.757 & 0.308 & $\mathrm{C}$ & 0.683 & -1.667 & 0.297 \\
\hline $\mathrm{H}$ & $\begin{array}{ll}0.999 & -2.717\end{array}$ & 0.500 & $\mathrm{H}$ & 0.307 & -2.476 & -0.231 & $\mathrm{H}$ & 0.019 & -2.362 & -0.226 \\
\hline $\mathrm{H}$ & $2.146-2.160$ & 1.709 & $\mathrm{H}$ & 1.432 & -2.305 & 1.109 & $\mathrm{H}$ & 1.089 & -2.211 & 1.152 \\
\hline $\mathrm{C}$ & $2.195 \quad-1.043$ & -0.128 & $\mathrm{C}$ & 1.965 & -1.132 & -0.625 & $\mathrm{C}$ & 1.842 & -1.253 & -0.619 \\
\hline $\mathrm{H}$ & $2.885-1.728$ & -0.630 & $\mathrm{H}$ & 2.541 & -1.945 & -1.075 & $\mathrm{H}$ & 2.317 & -2.162 & -0.999 \\
\hline $\mathrm{H}$ & $1.495-0.689$ & -0.887 & $\mathrm{H}$ & 1.464 & -0.609 & -1.438 & $\mathrm{H}$ & 1.460 & -0.705 & -1.480 \\
\hline $\mathrm{C}$ & 3.0120 .139 & 0.399 & $\mathrm{C}$ & 2.939 & -0.175 & 0.073 & $\mathrm{C}$ & 2.908 & -0.415 & 0.086 \\
\hline $\mathrm{H}$ & $3.564 \quad 0.596$ & -0.430 & $\mathrm{H}$ & 3.633 & 0.228 & -0.674 & $\mathrm{H}$ & 3.708 & -0.158 & -0.608 \\
\hline $\mathrm{H}$ & $3.750-0.216$ & 1.122 & $\mathrm{H}$ & 3.537 & -0.722 & 0.806 & $\mathrm{H}$ & 3.355 & -0.990 & 0.905 \\
\hline $\mathrm{O}$ & $2.238 \quad 1.117$ & 1.082 & $\mathrm{O}$ & 2.294 & 0.871 & 0.780 & $\mathrm{O}$ & 2.400 & 0.822 & 0.596 \\
\hline $\mathrm{H}$ & $1.586 \quad 1.494$ & 0.455 & $\mathrm{H}$ & 1.652 & 1.339 & 0.169 & $\mathrm{H}$ & 1.037 & 1.820 & -0.302 \\
\hline
\end{tabular}




\section{anti-cis-MACRO $+\mathrm{NH}_{2} \mathrm{C}_{3} \mathrm{H}_{6} \mathrm{OH}$}

\begin{tabular}{|c|c|c|c|c|c|c|c|c|c|c|}
\hline \multirow[b]{2}{*}{$\mathrm{C}$} & \multicolumn{3}{|c|}{ Prereactive complex } & \multicolumn{4}{|c|}{ Transition State } & \multicolumn{3}{|c|}{ Product } \\
\hline & -1.4580 .677 & -0.209 & $\mathrm{C}$ & -1.235 & 0.314 & -0.238 & $\mathrm{C}$ & 0.680 & 0.355 & -0.503 \\
\hline $\mathrm{O}$ & -0.6171 .104 & -1.047 & $\mathrm{O}$ & -0.490 & 0.919 & -1.082 & $\mathrm{O}$ & 0.025 & 1.116 & 0.495 \\
\hline $\mathrm{O}$ & $0.259 \quad 2.096$ & -0.618 & $\mathrm{O}$ & 0.265 & 1.993 & -0.486 & $\mathrm{O}$ & -0.868 & 2.056 & -0.143 \\
\hline $\mathrm{H}$ & -1.4441 .111 & 0.782 & $\mathrm{H}$ & -1.482 & 0.870 & 0.660 & $\mathrm{H}$ & 0.971 & 1.025 & -1.316 \\
\hline $\mathrm{C}$ & $-2.440-0.291$ & -0.631 & $\mathrm{C}$ & -2.170 & -0.715 & -0.737 & $\mathrm{C}$ & 1.941 & -0.236 & 0.118 \\
\hline $\mathrm{C}$ & $\begin{array}{ll}-3.391 & -0.621\end{array}$ & 0.256 & $\mathrm{C}$ & -2.106 & -1.148 & -1.997 & $\mathrm{C}$ & 2.281 & -0.047 & 1.389 \\
\hline $\mathrm{C}$ & $-2.357-0.852$ & -2.022 & $\mathrm{C}$ & -3.199 & -1.196 & 0.250 & $\mathrm{C}$ & 2.795 & -1.029 & -0.837 \\
\hline $\mathrm{H}$ & $-2.401-0.058$ & -2.768 & $\mathrm{H}$ & -2.739 & -1.657 & 1.127 & $\mathrm{H}$ & 2.283 & -1.925 & -1.195 \\
\hline $\mathrm{H}$ & $-1.411-1.375$ & -2.170 & $\mathrm{H}$ & -3.812 & -0.368 & 0.612 & $\mathrm{H}$ & 3.055 & -0.437 & -1.718 \\
\hline $\mathrm{H}$ & $-3.173-1.548$ & -2.204 & $\mathrm{H}$ & -3.858 & -1.932 & -0.205 & $\mathrm{H}$ & 3.720 & -1.343 & -0.357 \\
\hline $\mathrm{H}$ & $-3.406-0.197$ & 1.251 & $\mathrm{H}$ & -1.371 & -0.764 & -2.689 & $\mathrm{H}$ & 1.673 & 0.538 & 2.061 \\
\hline $\mathrm{H}$ & $-4.173-1.324$ & 0.008 & $\mathrm{H}$ & -2.807 & -1.884 & -2.367 & $\mathrm{H}$ & 3.197 & -0.468 & 1.782 \\
\hline $\mathrm{N}$ & $0.334-1.023$ & 1.522 & $\mathrm{~N}$ & 0.082 & -0.835 & 0.924 & $\mathrm{~N}$ & -0.235 & -0.631 & -1.100 \\
\hline $\mathrm{H}$ & $\begin{array}{ll}0.732 & -0.188\end{array}$ & 1.939 & $\mathrm{H}$ & 0.668 & -0.103 & 1.332 & $\mathrm{H}$ & -2.090 & 0.056 & -1.287 \\
\hline $\mathrm{H}$ & $-0.129-1.549$ & 2.254 & $\mathrm{H}$ & -0.435 & -1.307 & 1.656 & $\mathrm{H}$ & 0.143 & -0.938 & -1.986 \\
\hline $\mathrm{C}$ & $1.433-1.820$ & 0.946 & $\mathrm{C}$ & 0.952 & -1.778 & 0.185 & $\mathrm{C}$ & -0.622 & -1.793 & -0.268 \\
\hline $\mathrm{H}$ & $\begin{array}{ll}0.999 & -2.717\end{array}$ & 0.500 & $\mathrm{H}$ & 0.315 & -2.416 & -0.430 & $\mathrm{H}$ & 0.224 & -2.175 & 0.312 \\
\hline $\mathrm{H}$ & $2.146-2.160$ & 1.709 & $\mathrm{H}$ & 1.473 & -2.427 & 0.897 & $\mathrm{H}$ & -0.923 & -2.585 & -0.958 \\
\hline $\mathrm{C}$ & $2.195 \quad-1.043$ & -0.128 & $\mathrm{C}$ & 1.976 & -1.055 & -0.695 & $\mathrm{C}$ & -1.788 & -1.489 & 0.681 \\
\hline $\mathrm{H}$ & $2.885-1.728$ & -0.630 & $\mathrm{H}$ & 2.561 & -1.817 & -1.217 & $\mathrm{H}$ & -2.011 & -2.399 & 1.246 \\
\hline $\mathrm{H}$ & $\begin{array}{ll}1.495 & -0.689\end{array}$ & -0.887 & $\mathrm{H}$ & 1.461 & -0.475 & -1.459 & $\mathrm{H}$ & -1.486 & -0.731 & 1.403 \\
\hline $\mathrm{C}$ & 3.0120 .139 & 0.399 & $\mathrm{C}$ & 2.941 & -0.140 & 0.067 & $\mathrm{C}$ & -3.064 & -1.040 & -0.028 \\
\hline $\mathrm{H}$ & 3.5640 .596 & -0.430 & $\mathrm{H}$ & 3.639 & 0.309 & -0.649 & $\mathrm{H}$ & -3.858 & -0.862 & 0.696 \\
\hline $\mathrm{H}$ & $3.750-0.216$ & 1.122 & $\mathrm{H}$ & 3.536 & -0.727 & 0.772 & $\mathrm{H}$ & -3.411 & -1.825 & -0.711 \\
\hline $\mathrm{O}$ & $2.238 \quad 1.117$ & 1.082 & $\mathrm{O}$ & 2.289 & 0.862 & 0.831 & $\mathrm{O}$ & -2.896 & 0.183 & -0.755 \\
\hline $\mathrm{H}$ & $1.586 \quad 1.494$ & 0.455 & $\mathrm{H}$ & 1.638 & 1.353 & 0.253 & $\mathrm{H}$ & -1.713 & 1.560 & -0.139 \\
\hline
\end{tabular}


syn- $\mathrm{CH}_{3} \mathrm{CHOO}+\mathrm{NH}_{2} \mathrm{C}_{3} \mathrm{H}_{6} \mathrm{OH}$

\begin{tabular}{|c|c|c|c|c|c|c|c|c|c|c|c|}
\hline \multirow[b]{2}{*}{$\mathrm{C}$} & \multicolumn{4}{|c|}{ Prereactive complex } & \multicolumn{4}{|c|}{ Transition State } & \multicolumn{3}{|c|}{ Product } \\
\hline & 1.831 & 0.793 & -0.458 & $\mathrm{C}$ & 1.591 & 0.828 & -0.428 & $\mathrm{C}$ & 1.141 & 1.006 & -0.294 \\
\hline $\mathrm{H}$ & 1.728 & 1.682 & -1.065 & & 1.544 & 1.678 & -1.100 & $\mathrm{H}$ & 1.099 & 1.667 & -1.172 \\
\hline $\mathrm{O}$ & 1.531 & -0.258 & -1.077 & $\mathrm{O}$ & 1.415 & -0.271 & -1.048 & $\mathrm{O}$ & 1.290 & -0.250 & -0.955 \\
\hline $\mathrm{O}$ & 1.614 & -1.457 & -0.361 & $\mathrm{O}$ & 1.547 & -1.451 & -0.236 & $\mathrm{O}$ & 1.578 & -1.297 & 0.006 \\
\hline C & 2.352 & 0.792 & 0.916 & $\mathrm{C}$ & 2.392 & 0.917 & 0.823 & $\mathrm{C}$ & 2.337 & 1.363 & 0.574 \\
\hline I & 3.262 & 0.184 & 0.939 & $\mathrm{H}$ & 3.415 & 0.622 & 0.576 & $\mathrm{H}$ & 3.253 & 1.235 & 0.001 \\
\hline $\mathrm{H}$ & 2.551 & 1.803 & 1.256 & $\mathrm{H}$ & 2.397 & 1.936 & 1.204 & $\mathrm{H}$ & 2.274 & 2.404 & 0.897 \\
\hline $\mathrm{H}$ & 1.648 & 0.287 & 1.579 & $\mathrm{H}$ & 2.036 & 0.217 & 1.572 & $\mathrm{H}$ & 2.382 & 0.719 & 1.448 \\
\hline $\mathrm{N}$ & -0.814 & 1.688 & 0.419 & $\mathrm{~N}$ & -0.315 & 1.283 & 0.454 & $\mathrm{~N}$ & -0.101 & 1.071 & 0.466 \\
\hline $\mathrm{H}$ & -0.659 & 1.049 & 1.192 & $\mathrm{H}$ & -0.342 & 0.557 & 1.172 & $\mathrm{H}$ & -0.633 & -0.691 & 1.271 \\
\hline $\mathrm{H}$ & -0.936 & 2.618 & 0.804 & $\mathrm{H}$ & -0.285 & 2.196 & 0.892 & $\mathrm{H}$ & -0.036 & 1.815 & 1.147 \\
\hline $\mathrm{C}$ & -2.043 & 1.271 & -0.285 & $\mathrm{C}$ & -1.523 & 1.137 & -0.393 & $\mathrm{C}$ & -1.340 & 1.211 & -0.328 \\
\hline $\mathrm{H}$ & -2.193 & 1.950 & -1.127 & $\mathrm{H}$ & -1.419 & 1.800 & -1.254 & $\mathrm{H}$ & -1.189 & 1.899 & -1.170 \\
\hline $\mathrm{H}$ & -2.933 & 1.356 & 0.354 & $\mathrm{H}$ & -2.406 & 1.469 & 0.164 & $\mathrm{H}$ & -2.088 & 1.666 & 0.326 \\
\hline $\mathrm{C}$ & -1.949 & -0.163 & -0.807 & $\mathrm{C}$ & -1.733 & -0.304 & -0.868 & $\mathrm{C}$ & -1.882 & -0.123 & -0.853 \\
\hline $\mathrm{H}$ & -2.836 & -0.361 & -1.418 & $\mathrm{H}$ & -2.644 & -0.322 & -1.473 & $\mathrm{H}$ & -2.794 & 0.082 & -1.421 \\
\hline $\mathrm{H}$ & -1.086 & -0.260 & -1.468 & $\mathrm{H}$ & -0.915 & -0.604 & -1.520 & $\mathrm{H}$ & -1.166 & -0.566 & -1.545 \\
\hline $\mathrm{C}$ & -1.884 & -1.241 & 0.278 & $\mathrm{C}$ & -1.882 & -1.334 & 0.258 & $\mathrm{C}$ & -2.216 & -1.128 & 0.248 \\
\hline $\mathrm{H}$ & -1.942 & -2.229 & -0.189 & $\mathrm{H}$ & -2.072 & -2.317 & -0.187 & $\mathrm{H}$ & -2.626 & -2.040 & -0.184 \\
\hline $\mathrm{H}$ & -2.746 & -1.148 & 0.944 & $\mathrm{H}$ & -2.747 & -1.088 & 0.880 & $\mathrm{H}$ & -2.976 & -0.712 & 0.920 \\
\hline $\mathrm{O}$ & -0.733 & -1.156 & 1.113 & $\mathrm{O}$ & -0.763 & -1.386 & 1.132 & $\mathrm{O}$ & -1.069 & -1.521 & 1.009 \\
\hline 1 & 0.060 & -1.398 & 0.589 & $\mathrm{H}$ & 0.067 & -1.543 & 0.601 & $\mathrm{H}$ & 0.682 & -1.642 & 0.190 \\
\hline
\end{tabular}




\section{$\left(\mathrm{CH}_{3}\right)_{2} \mathrm{CHOO}+\mathrm{NH}_{2} \mathrm{C}_{3} \mathrm{H}_{6} \mathrm{OH}$}

\begin{tabular}{|c|c|c|c|c|c|c|c|c|c|c|c|}
\hline \multirow[b]{2}{*}{$\mathrm{C}$} & \multicolumn{4}{|c|}{ Prereactive complex } & \multicolumn{4}{|c|}{ Transition State } & \multicolumn{3}{|l|}{ Product } \\
\hline & 1.771 & 0.641 & -0.576 & & 1.515 & 0.890 & -0.430 & $\mathrm{C}$ & 0.945 & 0.983 & -0.110 \\
\hline $\mathrm{O}$ & 1.324 & -0.416 & -1.102 & $\mathrm{O}$ & 1.366 & -0.251 & -1.018 & $\mathrm{O}$ & 1.034 & -0.312 & -0.727 \\
\hline $\mathrm{O}$ & 1.331 & -1.577 & -0.315 & $\mathrm{O}$ & 1.486 & -1.402 & -0.146 & $\mathrm{O}$ & 1.240 & -1.353 & 0.256 \\
\hline $\mathrm{C}$ & 2.315 & 0.621 & 0.795 & $\mathrm{C}$ & 2.368 & 0.981 & 0.801 & $\mathrm{C}$ & 2.086 & 1.211 & 0.879 \\
\hline $\mathrm{H}$ & 3.072 & -0.163 & 0.861 & $\mathrm{H}$ & 3.393 & 0.747 & 0.504 & $\mathrm{H}$ & 3.035 & 0.976 & 0.403 \\
\hline $\mathrm{H}$ & 2.719 & 1.590 & 1.072 & $\mathrm{H}$ & 2.346 & 1.987 & 1.218 & $\mathrm{H}$ & 2.107 & 2.255 & 1.197 \\
\hline $\mathrm{H}$ & 1.526 & 0.321 & 1.487 & $\mathrm{H}$ & 2.074 & 0.241 & 1.537 & $\mathrm{H}$ & 1.972 & 0.574 & 1.752 \\
\hline $\mathrm{C}$ & 1.687 & 1.862 & -1.411 & $\mathrm{C}$ & 1.559 & 2.027 & -1.416 & $\mathrm{C}$ & 1.081 & 1.910 & -1.325 \\
\hline $\mathrm{H}$ & 0.938 & 2.518 & -0.957 & $\mathrm{H}$ & 1.330 & 2.977 & -0.937 & $\mathrm{H}$ & 0.894 & 2.943 & -1.030 \\
\hline $\mathrm{H}$ & 2.644 & 2.386 & -1.417 & $\mathrm{H}$ & 2.569 & 2.090 & -1.827 & $\mathrm{H}$ & 2.088 & 1.839 & -1.730 \\
\hline $\mathrm{H}$ & 1.383 & 1.622 & -2.427 & $\mathrm{H}$ & 0.871 & 1.853 & -2.239 & $\mathrm{H}$ & 0.383 & 1.640 & -2.115 \\
\hline $\mathrm{N}$ & -1.239 & 1.874 & 0.657 & $\mathrm{~N}$ & -0.266 & 1.210 & 0.476 & $\mathrm{~N}$ & -0.329 & 1.109 & 0.623 \\
\hline $\mathrm{H}$ & -0.906 & 1.208 & 1.347 & $\mathrm{H}$ & -0.289 & 0.433 & 1.144 & $\mathrm{H}$ & -0.935 & -0.597 & 1.478 \\
\hline $\mathrm{H}$ & -1.422 & 2.746 & 1.140 & $\mathrm{H}$ & -0.227 & 2.090 & 0.977 & $\mathrm{H}$ & -0.242 & 1.861 & 1.293 \\
\hline $\mathrm{C}$ & -2.492 & 1.350 & 0.081 & $\mathrm{C}$ & -1.498 & 1.119 & -0.349 & $\mathrm{C}$ & -1.588 & 1.261 & -0.138 \\
\hline $\mathrm{H}$ & -2.808 & 2.033 & -0.711 & $\mathrm{H}$ & -1.403 & 1.813 & -1.186 & $\mathrm{H}$ & -1.487 & 1.963 & -0.970 \\
\hline $\mathrm{H}$ & -3.309 & 1.318 & 0.815 & $\mathrm{H}$ & -2.352 & 1.453 & 0.249 & $\mathrm{H}$ & -2.311 & 1.702 & 0.553 \\
\hline $\mathrm{C}$ & -2.310 & -0.050 & -0.504 & $\mathrm{C}$ & -1.753 & -0.301 & -0.861 & $\mathrm{C}$ & -2.151 & -0.069 & -0.655 \\
\hline $\mathrm{H}$ & -3.218 & -0.311 & -1.056 & $\mathrm{H}$ & -2.667 & -0.278 & -1.460 & $\mathrm{H}$ & -3.054 & 0.146 & -1.233 \\
\hline $\mathrm{H}$ & -1.492 & -0.044 & -1.228 & $\mathrm{H}$ & -0.945 & -0.606 & -1.523 & $\mathrm{H}$ & -1.437 & -0.535 & -1.334 \\
\hline $\mathrm{C}$ & -2.066 & -1.149 & 0.534 & $\mathrm{C}$ & -1.922 & -1.351 & 0.245 & $\mathrm{C}$ & -2.517 & -1.049 & 0.457 \\
\hline $\mathrm{H}$ & -2.090 & -2.126 & 0.042 & $\mathrm{H}$ & -2.111 & -2.324 & -0.222 & $\mathrm{H}$ & -2.921 & -1.969 & 0.037 \\
\hline $\mathrm{H}$ & -2.870 & -1.138 & 1.273 & $\mathrm{H}$ & -2.797 & -1.112 & 0.856 & $\mathrm{H}$ & -3.290 & -0.614 & 1.101 \\
\hline $\mathrm{O}$ & -0.850 & -0.996 & 1.261 & $\mathrm{O}$ & -0.817 & -1.422 & 1.130 & $\mathrm{O}$ & -1.391 & -1.429 & 1.255 \\
\hline $\mathrm{H}$ & -0.105 & -1.309 & 0.703 & $\mathrm{H}$ & 0.033 & -1.546 & 0.603 & $\mathrm{H}$ & 0.322 & -1.634 & 0.445 \\
\hline
\end{tabular}


syn-trans-MAVKO $+\mathrm{NH}_{2} \mathrm{C}_{3} \mathrm{H}_{6} \mathrm{OH}$

\begin{tabular}{|c|c|c|c|c|c|c|c|c|c|c|c|}
\hline \multirow[b]{2}{*}{$\mathrm{C}$} & \multicolumn{4}{|c|}{ Prereactive complex } & \multicolumn{4}{|c|}{ Transition State } & \multicolumn{3}{|c|}{ Product } \\
\hline & -1.391 & 0.602 & -0.302 & & -1.217 & 0.392 & -0.101 & $\mathrm{C}$ & -0.787 & 0.085 & 0.311 \\
\hline $\mathrm{O}$ & -0.390 & 0.801 & -1.069 & $\mathrm{O}$ & -0.493 & 0.863 & -1.089 & $\mathrm{O}$ & -0.115 & 0.765 & -0.768 \\
\hline $\mathrm{O}$ & 0.509 & 1.786 & -0.699 & $\mathrm{O}$ & 0.378 & 1.952 & -0.713 & $\mathrm{O}$ & 0.646 & 1.896 & -0.289 \\
\hline $\mathrm{C}$ & -1.544 & 1.415 & 0.918 & $\mathrm{C}$ & -1.682 & 1.347 & 0.965 & $\mathrm{C}$ & -1.548 & 1.068 & 1.193 \\
\hline $\mathrm{H}$ & -1.534 & 2.471 & 0.640 & $\mathrm{H}$ & -2.393 & 2.035 & 0.507 & $\mathrm{H}$ & -2.217 & 1.668 & 0.583 \\
\hline $\mathrm{H}$ & -2.446 & 1.167 & 1.466 & $\mathrm{H}$ & -2.177 & 0.828 & 1.783 & $\mathrm{H}$ & -2.137 & 0.542 & 1.944 \\
\hline $\mathrm{H}$ & -0.664 & 1.268 & 1.546 & $\mathrm{H}$ & -0.846 & 1.933 & 1.330 & $\mathrm{H}$ & -0.846 & 1.728 & 1.696 \\
\hline $\mathrm{C}$ & -2.287 & -0.424 & -0.784 & $\mathrm{C}$ & -2.148 & -0.640 & -0.628 & $\mathrm{C}$ & -1.693 & -0.847 & -0.480 \\
\hline $\mathrm{H}$ & -1.973 & -0.905 & -1.701 & $\mathrm{H}$ & -1.857 & -1.043 & -1.590 & $\mathrm{H}$ & -1.267 & -1.206 & -1.409 \\
\hline $\mathrm{C}$ & -3.426 & -0.784 & -0.185 & $\mathrm{C}$ & -3.264 & -1.054 & -0.037 & $\mathrm{C}$ & -2.910 & -1.241 & -0.130 \\
\hline $\mathrm{H}$ & -3.770 & -0.332 & 0.733 & $\mathrm{H}$ & -3.602 & -0.664 & 0.913 & $\mathrm{H}$ & -3.396 & -0.908 & 0.777 \\
\hline $\mathrm{H}$ & -4.047 & -1.560 & -0.608 & $\mathrm{H}$ & -3.891 & -1.801 & -0.503 & $\mathrm{H}$ & -3.470 & -1.923 & -0.754 \\
\hline $\mathrm{N}$ & 0.558 & -1.645 & 1.606 & $\mathrm{~N}$ & 0.014 & -0.641 & 0.958 & $\mathrm{~N}$ & 0.201 & -0.624 & 1.152 \\
\hline $\mathrm{H}$ & 0.961 & -0.791 & 1.977 & $\mathrm{H}$ & 0.689 & 0.058 & 1.290 & $\mathrm{H}$ & 1.958 & 0.333 & 1.344 \\
\hline $\mathrm{H}$ & 0.187 & -2.176 & 2.384 & $\mathrm{H}$ & -0.518 & -1.017 & 1.735 & $\mathrm{H}$ & -0.239 & -0.834 & 2.038 \\
\hline $\mathrm{C}$ & 1.628 & -2.408 & 0.939 & $\mathrm{C}$ & 0.781 & -1.712 & 0.268 & $\mathrm{C}$ & 0.843 & -1.850 & 0.622 \\
\hline $\mathrm{H}$ & 1.182 & -3.313 & 0.521 & $\mathrm{H}$ & 0.072 & -2.342 & -0.272 & $\mathrm{H}$ & 0.124 & -2.503 & 0.120 \\
\hline $\mathrm{H}$ & 2.413 & -2.736 & 1.636 & $\mathrm{H}$ & 1.257 & -2.337 & 1.028 & $\mathrm{H}$ & 1.208 & -2.401 & 1.492 \\
\hline $\mathrm{C}$ & 2.281 & -1.606 & -0.187 & $\mathrm{C}$ & 1.842 & -1.153 & -0.683 & $\mathrm{C}$ & 2.025 & -1.564 & -0.311 \\
\hline $\mathrm{H}$ & 2.937 & -2.274 & -0.753 & $\mathrm{H}$ & 2.356 & -2.004 & -1.138 & $3 \mathrm{H}$ & 2.408 & -2.522 & -0.675 \\
\hline $\mathrm{H}$ & 1.511 & -1.257 & -0.878 & $\mathrm{H}$ & 1.362 & -0.601 & -1.488 & $3 \mathrm{H}$ & 1.686 & -1.002 & -1.181 \\
\hline $\mathrm{C}$ & 3.123 & -0.417 & 0.282 & $\mathrm{C}$ & 2.884 & -0.255 & -0.006 & $5 \mathrm{C}$ & 3.172 & -0.817 & 0.366 \\
\hline $\mathrm{H}$ & 3.633 & 0.030 & -0.579 & $\mathrm{H}$ & 3.601 & 0.084 & -0.761 & $\mathrm{H}$ & 3.987 & -0.651 & -0.336 \\
\hline $\mathrm{H}$ & 3.896 & -0.763 & 0.972 & $\mathrm{H}$ & 3.446 & -0.826 & 0.739 & $\mathrm{H}$ & 3.569 & -1.412 & 1.197 \\
\hline $\mathrm{O}$ & 2.384 & 0.575 & 0.987 & $\mathrm{O}$ & 2.311 & 0.849 & 0.676 & $\mathrm{O}$ & 2.785 & 0.474 & 0.849 \\
\hline $\mathrm{H}$ & 1.785 & 1.025 & 0.358 & $\mathrm{H}$ & 1.671 & 1.327 & 0.058 & $\mathrm{H}$ & 1.526 & 1.495 & -0.132 \\
\hline
\end{tabular}




\section{syn-cis-MAVKO $+\mathrm{NH}_{2} \mathrm{C}_{3} \mathrm{H}_{6} \mathrm{OH}$}

\begin{tabular}{|c|c|c|c|c|c|c|c|c|c|c|c|}
\hline \multirow[b]{2}{*}{$\mathrm{C}$} & \multicolumn{4}{|c|}{ Prereactive complex } & \multicolumn{4}{|c|}{ Transition State } & \multicolumn{3}{|c|}{ Product } \\
\hline & -1.391 & 0.587 & -0.057 & & -1.190 & 0.381 & -0.161 & $\mathrm{C}$ & -0.786 & 0.123 & 0.531 \\
\hline $\mathrm{O}$ & -0.613 & 0.618 & -1.062 & $\mathrm{O}$ & -0.451 & 0.820 & -1.136 & & -0.335 & 0.480 & -0.779 \\
\hline $\mathrm{O}$ & 0.290 & 1.677 & -1.135 & $\mathrm{O}$ & 0.395 & 1.946 & -0.780 & $\mathrm{O}$ & 0.414 & 1.715 & -0.754 \\
\hline $\mathrm{C}$ & -1.311 & 1.640 & 0.973 & $\mathrm{C}$ & -1.648 & 1.344 & 0.903 & $\mathrm{C}$ & -1.418 & 1.310 & 1.261 \\
\hline $\mathrm{H}$ & -1.496 & 2.607 & 0.499 & $\mathrm{H}$ & -2.298 & 2.076 & 0.421 & $\mathrm{H}$ & -2.169 & 1.769 & 0.622 \\
\hline $\mathrm{H}$ & -2.021 & 1.460 & 1.775 & $\mathrm{H}$ & -2.216 & 0.829 & 1.676 & $\mathrm{H}$ & -1.905 & 0.973 & 2.177 \\
\hline $\mathrm{H}$ & -0.292 & 1.694 & 1.359 & $\mathrm{H}$ & -0.810 & 1.886 & 1.327 & $\mathrm{H}$ & -0.663 & 2.052 & 1.507 \\
\hline $\mathrm{C}$ & -2.364 & -0.493 & -0.023 & $\mathrm{C}$ & -2.163 & -0.661 & -0.587 & $\mathrm{C}$ & -1.837 & -0.948 & 0.296 \\
\hline $\mathrm{H}$ & -2.845 & -0.644 & 0.933 & $\mathrm{H}$ & -2.730 & -1.117 & 0.216 & $\mathrm{H}$ & -2.149 & -1.449 & 1.208 \\
\hline $\mathrm{C}$ & -2.691 & -1.249 & -1.075 & $\mathrm{C}$ & -2.384 & -1.013 & -1.848 & $\mathrm{C}$ & -2.394 & -1.284 & -0.860 \\
\hline $\mathrm{H}$ & -2.239 & -1.100 & -2.045 & $\mathrm{H}$ & -1.846 & -0.551 & -2.664 & $\mathrm{H}$ & -2.114 & -0.805 & -1.786 \\
\hline $\mathrm{H}$ & -3.428 & -2.033 & -0.981 & $\mathrm{H}$ & -3.124 & -1.763 & -2.092 & $\mathrm{H}$ & -3.155 & -2.051 & -0.902 \\
\hline $\mathrm{N}$ & 0.670 & -1.157 & 1.964 & $\mathrm{~N}$ & 0.023 & -0.692 & 0.938 & $\mathrm{~N}$ & 0.352 & -0.366 & 1.336 \\
\hline $\mathrm{H}$ & 1.115 & -0.249 & 2.050 & $\mathrm{H}$ & 0.683 & 0.018 & 1.281 & $\mathrm{H}$ & 2.040 & 0.665 & 1.024 \\
\hline $\mathrm{H}$ & 0.438 & -1.477 & 2.897 & $\mathrm{H}$ & -0.498 & -1.087 & 1.713 & $\mathrm{H}$ & 0.080 & -0.376 & 2.309 \\
\hline $\mathrm{C}$ & 1.629 & -2.085 & 1.338 & $\mathrm{C}$ & 0.812 & -1.735 & 0.230 & $\mathrm{C}$ & 0.954 & -1.669 & 0.967 \\
\hline $\mathrm{H}$ & 1.129 & -3.048 & 1.213 & $\mathrm{H}$ & 0.122 & -2.337 & -0.363 & $\mathrm{H}$ & 0.191 & -2.398 & 0.679 \\
\hline $\mathrm{H}$ & 2.511 & -2.267 & 1.968 & $\mathrm{H}$ & 1.264 & -2.393 & 0.978 & $\mathrm{H}$ & 1.439 & -2.051 & 1.869 \\
\hline $\mathrm{C}$ & 2.100 & -1.584 & -0.027 & $\mathrm{C}$ & 1.903 & -1.138 & -0.664 & $\mathrm{C}$ & 1.999 & -1.567 & -0.151 \\
\hline $\mathrm{H}$ & 2.676 & -2.382 & -0.506 & $\mathrm{H}$ & 2.457 & -1.971 & -1.105 & $\mathrm{H}$ & 2.384 & -2.573 & -0.343 \\
\hline $\mathrm{H}$ & 1.234 & -1.393 & -0.665 & $\mathrm{H}$ & 1.446 & -0.588 & -1.483 & $\mathrm{H}$ & 1.522 & -1.227 & -1.070 \\
\hline $\mathrm{C}$ & 2.986 & -0.336 & 0.019 & $\mathrm{C}$ & 2.892 & -0.222 & 0.066 & $\mathrm{C}$ & 3.176 & -0.656 & 0.183 \\
\hline $\mathrm{H}$ & 3.371 & -0.127 & -0.984 & $\mathrm{H}$ & 3.642 & 0.129 & -0.652 & $\mathrm{H}$ & 3.895 & -0.645 & -0.635 \\
\hline $\mathrm{H}$ & 3.848 & -0.522 & 0.664 & $\mathrm{H}$ & 3.424 & -0.781 & 0.841 & $\mathrm{H}$ & 3.698 & -1.023 & 1.075 \\
\hline $\mathrm{O}$ & 2.338 & 0.816 & 0.549 & $\mathrm{O}$ & 2.264 & 0.875 & 0.713 & $\mathrm{O}$ & 2.780 & 0.705 & 0.391 \\
\hline $\mathrm{H}$ & 1.690 & 1.145 & -0.108 & $\mathrm{H}$ & 1.647 & 1.342 & 0.062 & $\mathrm{H}$ & 1.330 & 1.394 & -0.622 \\
\hline
\end{tabular}




\section{Appendix: The absolute cross section of 1,3-diiodo-but-2-ene}

We use a method similar to our previous reports ${ }^{1,16}$ to determine the absolute UV absorption cross section of the precursor of MVKO, 1,3-diiodo-but-2-ene. The vapor of 1,3-diiodo-but-2ene was generated through blowing the $\mathrm{N}_{2}$ carrier gas, $f_{\mathrm{c}}$, over the precursor liquid surface, and was diluted with another $\mathrm{N}_{2}$ stream, $f_{\mathrm{D}}$, to targeted concentration before entering the UV absorption cell. The UV absorption spectra of the precursor were measured in an absorption cell (path length $L=75.3 \mathrm{~cm}$ ) with a $\mathrm{D}_{2}$ lamp (Hamamatsu, L12515) and an UV spectrometer (Ibsen photonic, FHW-380). The total consumption of 1,3-diiodo-but-2-ene was determined with its weight loss $\Delta W$, which was measured with an analytical balance (Shimadzu, AP225WD) before and after the spectra acquisition.

The cross section of 1,3-diiodo-but-2-ene can be deduced from the following equations:

$$
\begin{aligned}
& F_{\mathrm{T}}(t)=\left(f_{\mathrm{C}}(t)+f_{D}(t)\right) \frac{T}{273 K} \frac{760 \text { Torr }}{P} \\
& \Delta W=\int \frac{M_{\mathrm{w}}}{N_{\mathrm{A}}} n(t) F(t) d t=\int \frac{M_{\mathrm{w}}}{N_{\mathrm{A}}} \frac{A b s(t)}{\sigma L} F(t) d t \\
& \sigma=\frac{M_{\mathrm{w}}}{N_{\mathrm{A}} \Delta W L} \int F(t) A b s(t) d t
\end{aligned}
$$

The total actual volume flow rate $F_{\mathrm{T}}$ can be converted from the readings of the mass flow controllers, $f_{\mathrm{C}}$ and $f_{\mathrm{D}}$, which are in the unit of standard volume flow rate (equivalent flow rate at $273 \mathrm{~K}, 760$ Torr). $T$ would be temperature and $P$ would be pressure, which are kept constant during the measurement. $n(t)$ is the number density of the reactant. The integration of $n(t) F(t)$ over $t$ gives the total number of the 1,3-diiodo-but-2-ene molecules, which can be related to the total mass $\Delta W$ via the molecular weight $M_{\mathrm{w}}$ and the Avogadro number, $N_{\mathrm{A}}$. Then from BeerLambert law, $A b s(t)=n(t) \sigma L$, we can obtain the value of the cross section $\sigma$.

The experimental conditions and results are shown in Table S15-16 and Figure S21. 


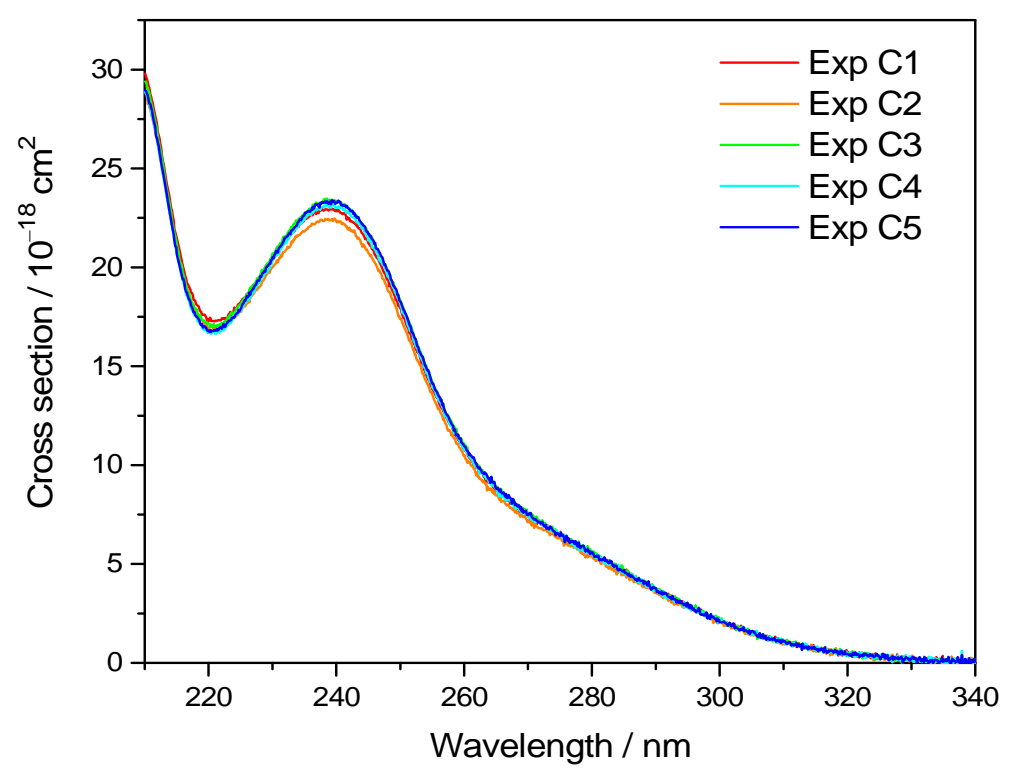

Figure S21. The UV absorption cross sections of 1,3-diiodo-but-2-ene

Table S15. Summary of the experimental conditions of the measurement of UV absorption cross section. The experiments are conduct at $298 \mathrm{~K}$ while both the $f_{\mathrm{c}}$ and $f_{\mathrm{d}}$ are $1000 \mathrm{sccm}$.

\begin{tabular}{cccc}
\hline Exp\# & $\begin{array}{c}P \\
\text { Torr }\end{array}$ & $\begin{array}{l}\Delta W \\
/ \mathrm{mg}\end{array}$ & $\begin{array}{c}\sigma(240 \mathrm{~nm}) \\
/ 10^{-18} \mathrm{~cm}^{2}\end{array}$ \\
\hline $\mathrm{C} 1$ & 264 & 49.0 & 22.9 \\
\hline $\mathrm{C} 2$ & 400 & 27.0 & 22.4 \\
\hline $\mathrm{C} 3$ & 393 & 30.6 & 23.3 \\
\hline $\mathrm{C} 4$ & 495 & 21.7 & 23.0 \\
\hline $\mathrm{C} 5$ & 408 & 27.5 & 23.3 \\
\hline & Average: & 23.0 \\
& &
\end{tabular}

${ }^{\text {a }}$ Standard deviation of the five data points 
Table S16. The averaged UV absorption cross sections of 1,3-diiodo-but-2-ene

\begin{tabular}{|c|c|}
\hline $\begin{array}{l}\text { Wavelength } \\
\text { / nm }\end{array}$ & $\stackrel{\sigma}{\sigma} \mathrm{cm}^{-18}$ \\
\hline 210.61 & 28.6 \\
\hline 211.79 & 26.9 \\
\hline 212.96 & 24.8 \\
\hline 214.14 & 22.6 \\
\hline 215.31 & 20.6 \\
\hline 216.48 & 19.0 \\
\hline 217.66 & 18.0 \\
\hline 218.83 & 17.4 \\
\hline 220.00 & 17.0 \\
\hline 221.18 & 17.0 \\
\hline 222.35 & 17.1 \\
\hline 223.52 & 17.5 \\
\hline 224.70 & 17.9 \\
\hline 225.87 & 18.4 \\
\hline 227.05 & 18.9 \\
\hline 228.22 & 19.5 \\
\hline 229.39 & 20.1 \\
\hline 230.56 & 20.6 \\
\hline 231.74 & 21.2 \\
\hline 232.91 & 21.7 \\
\hline 234.08 & 22.1 \\
\hline 235.26 & 22.5 \\
\hline 236.43 & 22.8 \\
\hline 237.60 & 23.0 \\
\hline 238.77 & 23.0 \\
\hline 239.94 & 23.0 \\
\hline 241.11 & 22.8 \\
\hline 242.29 & 22.5 \\
\hline 243.46 & 22.1 \\
\hline 244.63 & 21.6 \\
\hline 245.80 & 20.9 \\
\hline 246.97 & 20.3 \\
\hline 248.14 & 19.4 \\
\hline 249.31 & 18.5 \\
\hline 250.48 & 17.6 \\
\hline 251.65 & 16.7 \\
\hline 252.82 & 15.7 \\
\hline 253.99 & 14.8 \\
\hline 255.16 & 13.9 \\
\hline 256.32 & 13.1 \\
\hline
\end{tabular}

$\begin{array}{ll}257.49 & 12.3 \\ 258.66 & 11.6 \\ 259.83 & 10.9 \\ 260.99 & 10.3 \\ 262.16 & 9.8 \\ 263.33 & 9.4 \\ 264.49 & 9.0 \\ 265.66 & 8.6 \\ 266.82 & 8.2 \\ 267.99 & 7.9 \\ 269.15 & 7.6 \\ 270.32 & 7.4 \\ 271.48 & 7.1 \\ 272.64 & 6.9 \\ 273.81 & 6.7 \\ 274.97 & 6.5 \\ 276.13 & 6.2 \\ 277.29 & 6.0 \\ 278.45 & 5.8 \\ 279.61 & 5.6 \\ 280.77 & 5.4 \\ 281.93 & 5.1 \\ 283.09 & 5.0 \\ 284.25 & 4.7 \\ 285.41 & 4.5 \\ 286.56 & 4.3 \\ 287.72 & 4.1 \\ 288.88 & 3.9 \\ 290.03 & 3.7 \\ 291.19 & 3.5 \\ 292.34 & 3.3 \\ 293.50 & 3.1 \\ 294.65 & 2.9 \\ 295.80 & 2.7 \\ 296.95 & 2.6 \\ 298.10 & 2.4 \\ 299.25 & 2.2 \\ 300.40 & 2.1 \\ 301.55 & 1.9 \\ 302.70 & \end{array}$

$305.00 \quad 1.5$

$306.14 \quad 1.4$

$307.29 \quad 1.3$

$308.43 \quad 1.2$

$309.58 \quad 1.1$

$310.72 \quad 1.0$

$311.86 \quad 0.9$

$313.00 \quad 0.8$

$314.14 \quad 0.8$

$315.28 \quad 0.7$

$316.42 \quad 0.6$

$317.56 \quad 0.6$

$318.70 \quad 0.5$

$319.84 \quad 0.5$

$320.97 \quad 0.4$

$322.11 \quad 0.4$

$323.24 \quad 0.4$

$324.38 \quad 0.3$

$325.51 \quad 0.3$

$326.64 \quad 0.3$

$327.77 \quad 0.2$

$328.90 \quad 0.2$

$330.03 \quad 0.2$

$331.16 \quad 0.2$

$332.28 \quad 0.2$

$333.41 \quad 0.1$

$334.53 \quad 0.1$

$335.66 \quad 0.1$

$336.78 \quad 0.1$

$337.90 \quad 0.1$

$339.02 \quad 0.1$

$340.14 \quad 0.1$

$341.26 \quad 0.0$

$342.38 \quad 0.0$

$343.49 \quad 0.0$

$344.61 \quad 0.1$

$345.72 \quad 0.0$

$346.83 \quad 0.0$

$347.95 \quad 0.0$

$349.06 \quad 0.0$ 


\section{REFERENCES}

1. Kuo, M. T.; Takahashi, K.; Lin, J. J. M., Reactions of Criegee Intermediates are Enhanced by Hydrogen-Atom Relay Through Molecular Design. ChemPhysChem 2020, 21 (18), 2056-2059.

2. Chang, Y. P.; Chang, C. H.; Takahashi, K.; Lin, J. J. M., Absolute UV absorption cross sections of dimethyl substituted Criegee intermediate $\left(\mathrm{CH}_{3}\right)_{2} \mathrm{COO}$. Chemical Physics Letters 2016, 653, 155-160.

3. Bickelhaupt, F. M.; Houk, K. N., Analyzing Reaction Rates with the Distortion/Interaction-Activation Strain Model. Angewandte Chemie - International Edition 2017, 56 (34), 10070-10086.

4. Watson, N. A. I.; Black, J. A.; Stonelake, T. M.; Knowles, P. J.; Beames, J. M., An Extended Computational Study of Criegee Intermediate-Alcohol Reactions. J. Phys. Chem. A 2019, 123 (1), 218-229.

5. Chhantyal-Pun, R.; Rotavera, B.; McGillen, M. R.; Khan, M. A. H.; Eskola, A. J.; Caravan, R. L.; Blacker, L.; Tew, D. P.; Osborn, D. L.; Percival, C. J. et al. Criegee Intermediate Reactions with Carboxylic Acids: A Potential Source of Secondary Organic Aerosol in the Atmosphere. ACS Earth Space Chem. 2018, 2 (8), 833-842.

6. Georgievskii, Y.; Klippenstein, S. J., Long-range transition state theory. J. Chem. Phys. 2005, 122 (19), 194103.

7. Kuwata, K. T.; Guinn, E. J.; Hermes, M. R.; Fernandez, J. A.; Mathison, J. M.; Huang, K., A Computational Re-examination of the Criegee Intermediate-Sulfur Dioxide Reaction. J. Phys. Chem. A 2015, 119 (41), 10316-10335.

8. Louie, M. K.; Francisco, J. S.; Verdicchio, M.; Klippenstein, S. J.; Sinha, A., Dimethylamine Addition to Formaldehyde Catalyzed by a Single Water Molecule: A Facile Route for Atmospheric Carbinolamine Formation and Potential Promoter of Aerosol Growth. The Journal of Physical Chemistry A 2016, 120 (9), 1358-1368.

9. Singleton, D. L.; Cvetanovic, R. J., Temperature dependence of the reaction of oxygen atoms with olefins. J. Am. Chem. Soc. 1976, 98 (22), 6812-6819.

10. Foreman, E. S.; Kapnas, K. M.; Murray, C., Reactions between Criegee Intermediates and the Inorganic Acids $\mathrm{HCl}$ and $\mathrm{HNO}_{3}$ : Kinetics and Atmospheric Implications. Angew. Chem. Int. Ed. 2016, 55 (35), 10419-10422.

11. Long, B.; Wang, Y.; Xia, Y.; He, X.; Bao, J. L.; Truhlar, D. G., Atmospheric Kinetics: Bimolecular Reactions of Carbonyl Oxide by a Triple-Level Strategy. J. Am. Chem. Soc. 2021, 143 (22), 8402-8413.

12. Vereecken, L.; Novelli, A.; Taraborrelli, D., Unimolecular decay strongly limits the atmospheric impact of Criegee intermediates. Physical Chemistry Chemical Physics 2017, 19, 31599-31612.

13. Caravan, R. L.; Vansco, M. F.; Au, K.; Khan, M. A. H.; Li, Y.-L.; Winiberg, F. A. F.; Zuraski, K.; Lin, Y.-H.; Chao, W.; Trongsiriwat, N. et al. Direct kinetic measurements and theoretical predictions of an isoprene-derived Criegee intermediate. Proceedings of the National Academy of Sciences 2020, 117 (18), 9733-9740.

14. Huang, H.-L.; Chao, W.; Lin, J. J.-M., Kinetics of a Criegee intermediate that would survive high humidity and may oxidize atmospheric $\mathrm{SO}_{2}$. Proceedings of the National Academy of Sciences 2015, 112, 10857-10862. 
15. Ruscic, B., Active thermochemical tables: Water and water dimer. Journal of Physical Chemistry A 2013, 117 (46), 11940-11953.

16. Li, Y.-L.; Kuo, M.-T.; Lin, J. J.-M., Unimolecular decomposition rates of a methylsubstituted Criegee intermediate syn- $\mathrm{CH}_{3} \mathrm{CHOO}$. RSC Advances 2020, 10 (14), 8518-8524. 